\title{
Quantifying the association of natal household wealth with women's early marriage in Nepal
}

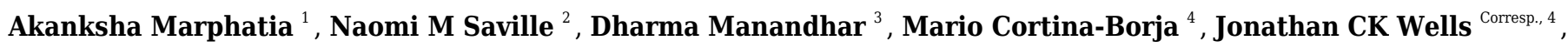 \\ Alice Reid ${ }^{1}$ \\ 1 Department of Geography, University of Cambridge, Cambridge, United Kingdom \\ 2 Institute for Global Health, University College London, University of London, London, United Kingdom \\ 3 Mother and Infant Research Activities, Kathmandu, Nepal \\ ${ }^{4}$ Great Ormond Street Institute of Child Health, University College London, University of London, London, United Kingdom \\ Corresponding Author: Jonathan CK Wells \\ Email address: Jonathan.Wells@ucl.ac.uk
}

Background. Women's early marriage (<18 years) is a critical global health issue affecting 650 million women worldwide. It is associated with a range of adverse maternal physical and mental health outcomes, including early childbearing, child undernutrition and morbidity. Poverty is widely asserted to be the key risk factor driving early marriage. However, most studies do not measure wealth in the natal household, but instead, use marital household wealth as a proxy for natal wealth. Further research is required to understand the key drivers of early marriage.

Methods. We investigated whether natal household poverty was associated with marrying early, independently of women's lower educational attainment and broader markers of household disadvantage. Data on natal household wealth (material asset score) for 2,432 women aged 18-39 years was used from the cluster-randomized Low Birth Weight South Asia Trial in lowland rural Nepal. Different early marriage definitions $(<15,<16,<17$ and $<18$ years) were used because most of our population marries below the conventional 18-year cut-off. Logistic mixed-effects models were fitted to estimate the probabilities, derived from adjusted Odds Ratios, of (a) marrying at different early ages for the full sample and for the uneducated women, and (b) being uneducated in the first place.

Results. Women married at median age 15 years (interquartile range 3 ), and only $18 \%$ married $\geq 18$ years. Two-thirds of the women were entirely uneducated. We found that, rather than poverty, women's lower education was the primary factor associated with early marriage, regardless of how 'early' is defined. Neither poverty nor other markers of household disadvantage were associated with early marriage at any age in the uneducated women. However, poverty was associated with women being uneducated.

Conclusion. When assets are measured in the natal household in this population, there is no support for the conventional hypothesis that household poverty is associated with daughters' early marriage, but it is associated with not going to school. We propose that improving access to free education would both reduce early marriage and have broader benefits for maternal and child health and gender equality. 


\section{Quantifying the association of natal household wealth with women's early marriage in Nepal}

3

4

5

6 Jonathan CK Wells ${ }^{4+}$ and Alice M Reid ${ }^{1+}$

7

8 +Joint senior authors (Jonathan CK Wells and Alice M Reid)

9

1. Department of Geography, University of Cambridge, Cambridge, UK

11 2. Institute for Global Health, University College London, UK

12 3. Mother and Infant Research Activities, Kathmandu, Nepal

4. Population, Policy and Practice Research and Teaching Department, UCL Great Ormond Street Institute of Child Health, London, UK 


\section{Abstract}

23

24

25

26

27

28

29

30

31

32

33

34

35

36

37

38

39

40

41

42

43

44

45

46

47

48

Background. Women's early marriage ( $<18$ years) is a critical global health issue affecting 650 million women worldwide. It is associated with a range of adverse maternal physical and mental health outcomes, including early childbearing, child undernutrition and morbidity. Poverty is widely asserted to be the key risk factor driving early marriage. However, most studies do not measure wealth in the natal household, but instead, use marital household wealth as a proxy for natal wealth. Further research is required to understand the key drivers of early marriage.

Methods. We investigated whether natal household poverty was associated with marrying early, independently of women's lower educational attainment and broader markers of household disadvantage. Data on natal household wealth (material asset score) for 2,432 women aged 18-39 years was used from the cluster-randomized Low Birth Weight South Asia Trial in lowland rural Nepal. Different early marriage definitions $(<15,<16,<17$ and $<18$ years) were used because most of our population marries below the conventional 18-year cut-off. Logistic mixed-effects models were fitted to estimate the probabilities, derived from adjusted Odds Ratios, of (a) marrying at different early ages for the full sample and for the uneducated women, and (b) being uneducated in the first place.

Results. Women married at median age 15 years (interquartile range 3 ), and only $18 \%$ married $\geq 18$ years. Two-thirds of the women were entirely uneducated. We found that, rather than poverty, women's lower education was the primary factor associated with early marriage, regardless of how 'early' is defined. Neither poverty nor other markers of household disadvantage were associated with early marriage at any age in the uneducated women. However, poverty was associated with women being uneducated.

Conclusion. When assets are measured in the natal household in this population, there is no support for the conventional hypothesis that household poverty is associated with daughters' early marriage, but it is associated with not going to school. We propose that improving access to free education would both reduce early marriage and have broader benefits for maternal and child health and gender equality. 
53

54

55

56

57

58

59

60

61

62

63

64

65

66

67

68

69

70

\section{Introduction}

Women's early reproduction is detrimental to both maternal and child health (Finlay, Özaltin \& Canning, 2011; Fall et al., 2016). However, in many societies, strong cultural norms mean that the vast majority of women marry before having children. In such societies, early marriage is therefore the gateway to early childbearing. Since early marriage also has broader implications for women's health, it is a crucial global health issue in its own right (Marphatia, Amable \& Reid, 2017).

Globally, 20\% of women aged 20-24 years marry or enter into a formal union before 18 years of age (UNICEF, 2021). Early marriage is associated with a range of penalties for women. These include less education, under-nutrition, lower access to contraception and healthcare, early childbearing, and higher morbidity and mortality during pregnancy and labor (Godha, Hotchkiss \& Gage, 2013; Raj \& Boehmer, 2013; Ganchimeg et al., 2014; Raj et al., 2014; Delprato et al., 2015; Goli, Rammohan \& Singh, 2015; Marphatia et al., 2021a; Wells et al., 2021). These disadvantages are likely to propagate adverse effects to the next generation (Bates, Maselko \& Schuler, 2007; Marphatia, Amable \& Reid, 2017; Chari et al., 2017).

The United Nations (UN) defines 'child or early marriage' using a cut-off of $<18$ years (UN General Assembly, 2014, 2018). However, among the Maithili-speaking Madhesi population in Nepal, where our study is based, most women marry well below this threshold, around a median age of 16.5 years (MOHP, New ERA \& ICF International, 2017). In this population, it would therefore be more informative to investigate the factors associated with marrying at different early marriage ages.

In most studies using the $<18$ years cut-off to define early marriage, poverty in women's natal household, where they are born and raised, is widely suggested to drive early marriage across the global South, including in Nepal (ICRW, 2006; Chaudhuri, 2015; Hodgkinson, 2016). However, most studies measure material assets (as an index of wealth) in the marital household only after women have already married, and then use this information as a proxy for the natal household's wealth prior to marriage (Raj et al., 2014; Delprato et al., 2015; Wodon et al., 2017; Scott et al., 2021). This practice therefore relies on an assumption that women are likely to marry into households of similar wealth as their natal homes. Wealth of natal and marital households might indeed be correlated, but a severe shortage of data on natal wealth means that there is little evidence for this assumption.

The wealth of the natal and marital households might therefore also be uncorrelated. For example, some studies find that younger marriages ( $<15$ years) may in part be driven by girls wanting to marry into economically better-off marital households, as a way of escaping the poverty of their natal home (Human Rights Watch, 2016). However, as wealth was measured in neither the natal nor marital household in this qualitative study, it is unclear whether the aims of these families were achieved. Moreover, some poorer families are able to educate their daughters to secondary school level, and this is then leveraged to marry them into wealthier households with more educated husbands (Fafchamps \& Shilpi, 2011; Jackson, 2012; Boyden, 2013). We argue, therefore, that using wealth of the marital household, where women end up after marriage, to represent wealth of the natal household, where women came from prior to marriage, is inappropriate when investigating the potential role of poverty in driving early marriage. 
99

100

101

102

103

104

105

106

107

108

109

110

111

112

113

114

115

116

117

118

119

120

121

122

123

124

125

126

127

128

129

130

131

132

133

134

135

136

137

138

139

140

141

142

143

144

Attributing wealth to the correct household is crucial in this context, because it reflects not only the family's socio-economic status but also its 'spatial niche'. This term refers to the physical habitat or space within which a household is geographically located, and reflects proximity and accessibility to a range of resources and people. Collectively, these characteristics are likely to shape the natal household's intentions around the timing of their daughter's marriage.

Misinterpreting the source of the natal household's interests (by using marital household assets) therefore means that we have an inadequate understanding of how both wealth and other related factors may be associated with early marriage.

Using data on natal households from a cluster-randomized trial in lowland rural Nepal, we investigate the independent associations of natal household poverty, as well as other socioeconomic factors, with different age groupings of early marriage. We also investigate the contribution of education to early marriage, and whether broader socio-economic factors are associated with women being uneducated in the first place.

\section{What do we know about poverty's association with early marriage?}

To date, most studies which investigate the link between wealth and age at marriage have focused on women after they have married. Clearly, it is difficult to measure natal household wealth after girls have already married and moved to their marital households. However, these studies assume that marital household assets are a proxy for the natal household's assets (wealth) without appropriate supporting evidence. Studies relating to Nepal vary in whether daughters from the poorest (Guragain et al., 2017), or the wealthiest (Aryal, 2007) households have the highest risk of marrying early. Other studies find an inconsistent relationship between wealth and marriage age (Raj et al., 2014) or no relationship at all (Pandey, 2017).

Some studies have used household wealth data appropriately, but in two different ways. One group of studies has described the proportion of women married $<18$ years stratified by marital wealth quintiles without making an assumption that this also represents wealth in the natal household. These studies consistently find that in impoverished regions of the world, including Nepal, the poorest marital household quintile has the largest proportion of women married $<18$ years (ICRW, 2006; UNFPA, 2012; UNICEF \& UNFPA, 2017; MacQuarrie \& Juan, 2019). Fewer studies have first measured wealth in the natal household itself, and then investigated if this is associated with the likelihood of women marrying early (Muchomba, 2021). In India, one study found that girls from poorer natal households were more likely to marry early (Singh \& Espinoza Revollo, 2016), whereas another study, which measured wealth at several time-points from the daughter's birth through to adolescence, found no association between wealth and early marriage (Marphatia et al., 2021b). For Nepal, we could only find one such study, which produced a less consistent pattern, whereby it was not the poorest, but the second poorest households whose daughters were married earliest (Bajracharaya and Amin 2012). Collectively, these studies suggest that the relationship between poverty and early marriage is not as strong when wealth is measured in natal households, and that using wealth in the marital household as a proxy for wealth in the natal household may be inappropriate.

Many of the insights on how poverty may push girls into early marriage come from qualitative literature, where household wealth is neither measured nor quantified. Nevertheless, such work

Peer] reviewing PDF | (2021:07:63393:1:0:NEW 21 Sep 2021) 
145 does offer valuable insights on subjective perspectives and decision-making around marriage.

146 Several studies from Nepal have identified a strong economic rationale for natal households to

147 marry daughters at a young age, related to material poverty: specifically in relation to the costs of

148 caring (food, clothes) for daughters and paying for their education (Verma, Sinha \& Khanna, 2013;

149 Chaudhuri, 2015; Human Rights Watch, 2016; Samuels et al., 2017). The custom of dowry (illegal,

150 but typically still paid from the natal to marital household) is also likely to contribute to early

151 marriage. Dowry generally demands a substantial proportion of a household's income, and this is

152 greater for families with several daughters (Sah, 2012; Pesando \& Abufhele, 2019). As dowry

153 tends to increase with age and education level, it may lower household investment in daughters

154 schooling and also incentivize early marriage (Sah, 2012; Hodgkinson, 2016; Human Rights

155 Watch, 2016; Karim, Greene \& Picard, 2016).

156

157 Hence, in the poorest families, girls may be perceived as an economic burden and thus the earlier

158 they are married, the better the natal household's economic welfare (Hodgkinson, 2016;

159 Guragain et al., 2017). However, one study from Nepal reporting both attitudinal and

160 quantitative data found that the primary drivers of early marriage were family pressure, socio-

161 cultural norms, low education and food insecurity; income poverty was cited as a less important

162 factor (Maharjan et al., 2012).

163

164

\section{Other markers of disadvantage and early marriage}

165 Beyond low material assets, other markers of disadvantage may also be associated with early

166 marriage. For example, education is a key factor associated with marriage age, and studies

167

168 generally find that girls' lower educational attainment (years of schooling completed) increases their risk of marrying early (Raj et al., 2014; Delprato et al., 2015; Sekine \& Hodgkin, 2017; Marphatia et al., 2020; Scott et al., 2021). The association between poverty and early marriage may therefore vary by girls' education level, and poverty may also contribute to whether girls are educated in the first place, because of the costs associated with schooling (e.g. fees, books, uniforms, etc) (Verma, Sinha \& Khanna, 2013; Chaudhuri, 2015; Samuels et al., 2017).

To understand the association between poverty and the timing of women's marriage, we also need to consider other relevant socio-economic factors. In rural contexts, agrarian land-holding is another relevant marker of household wealth (Fisher \& Naidoo, 2016). Landlessness may increase the risk of food insecurity, which in turn has been associated with both lower schooling and earlier marriage (Moock \& Leslie, 1986; UNICEF, 2014). Caste affiliation is also linked to socio-economic status, with girls from disadvantaged castes generally completing less education and also marrying < 18 years (Stash \& Hannum, 2001; Sah, 2018; Devkota, Eklund \& Wagle, 2020). There is much less literature on the role of the natal household's geographic location in relation to early marriage, but greater distance to school has been found to be a key constraint to accessing education (Jamison \& Lockheed, 1987; Ayral, 2014; Devkota \& Upadhyay, 2015).

184 Thus, if schooling is not a viable option, marrying daughters early may alleviate household financial pressures and food insecurity (Maharjan et al., 2012; Human Rights Watch, 2016; Samuels et al., 2017).

189

Socio-cultural norms are also likely to shape both the timing of marriage and the amount of education that girls are likely to complete. Bicchiere et al. (2014) define these normative social preferences as 'moral rules' that govern decision-making relating to women's life options, 
191 whether they refer to marriage, chastity, education, employment, etc. Failing to conform to these

192

193

194

195

196

197

198

199

200

201

202

203

204

205

206

207

208

209

210

211

212

213

214

215

216

217

218

219

220

221

222

223

224

225

226

227

228

229

230

231

232

233

234

235 norms may adversely affect a girl's marital options, and also her natal household's social standing in the community (Caldwell, Reddy \& Caldwell, 1983; Maertens, 2011, 2013). However, such norms can also change over time. Several studies have suggested that secular changes in attitudes and norms, coupled with widespread advocacy for minimum marriage age legislation, improvements in household wealth, and increased girls' educational attainment, are collectively likely to explain the overall decrease in early marriage over the past $\sim 15$ years across South Asia (Raj, McDougal \& Rusch, 2012; Allendorf \& Thornton, 2015; MacQuarrie \& Juan, 2019; Prakash et al., 2020; Scott et al., 2021).

\section{Study aim and hypotheses}

Our study aims to contribute new insights on the economic and social drivers of women's early marriage and their lack of education in low-income settings. Using objective data on wealth and broader markers of disadvantage measured in the natal household on 2,432 women aged 18-39 years from lowland rural Nepal, we investigate whether natal household poverty is associated with marrying early. We define 'early marriage' using several different age groupings, because most women in our population marry well below the 18 -year threshold (universal minimum legal age) conventionally used to define early marriage. This is crucial because if we only use the 18year threshold, we might miss identifying the factors associated with variability in age at marriage as it is experienced in this early-marrying population.

Since two-thirds of our sample are entirely uneducated, we also investigate whether poverty is associated with early marriage in uneducated women, and whether poverty is associated with women being uneducated in the first place. The uneducated women are interesting to examine on their own because for this group, variability in education cannot confound the association between wealth and marriage age. Our models adjust for women's age, to capture potential cohort effects and which may indicate secular changes in social norms over time. To ensure observed associations between poverty and early marriage are not an artefact of related factors, we include women's education level as another key exposure, and also broader markers of socioeconomic disadvantage measured in women's natal household: agrarian land-holding, geographic location and caste affiliation.

We investigate four hypotheses:

(1) that natal household poverty is associated with marrying early, using different ages to define this outcome: $<15,<16,<17$ and $<18$ years, in each case compared to marrying $\geq 18$ years;

(2) that women's lower educational attainment, independent of natal household poverty and broader markers of socio-economic disadvantage, is associated with early marriage: $<15$, $<16,<17$ and $<18$ years, in each case compared to marrying $\geq 18$ years;

(3) that amongst uneducated women, poverty, independent of broader markers of socioeconomic disadvantage, is associated with early marriage at different ages;

(4) that natal household poverty, independent of broader markers of socio-economic disadvantage, is associated with women being uneducated.

\section{Materials \& Methods}


236 Our study is based on data from the Low Birth Weight South Asia Trial (LBWSAT), which

237 assessed the impact of three pregnancy interventions on birth weight and infant growth (Saville

238 et al., 2018). This cluster-randomized control trial was conducted across 80 geographic clusters

239 in Dhanusha and Mahottari districts in Province 2 of the Terai region bordering Bihar state in

240 India. Married pregnant women were randomized to one of four intervention arms: Participatory Learning and Action (PLA) behavior change intervention in Women's Groups, PLA with unconditional cash transfers, PLA with a fortified blended food supplement, or a control group

243

244

245 25,090 married pregnant women aged 10-49 years in the home that they were residing in during pregnancy (Saville et al., 2016).

Research ethics approval to conduct the trial was granted by the Nepal Health Research Council (108/2012) and University College London (UCL) Research Ethics Committee (4198/001). Village Development Committee secretaries consented for villages to participate in the trial. Women gave written consent and guardians consented to the participation of married adolescents $<18$ years of age. Further ethical approvals for secondary analyses of LBWSAT data for this analysis were granted from the Nepal Health Research Council (292/2018), the Research Ethics Committees at UCL (0326/015) and the University of Cambridge (1016).

Marriages in the Maithili-speaking Madhesi population of our study are generally arranged by parents or close relatives, with girls having little say over the timing and choice of spouse (Maharjan \& Sah, 2012; Clarke, 2013). In 2016, the Maithili-speaking Madhesi women had the lowest median age at marriage (16.5 years) nationwide (MOHP, New ERA \& ICF International, 2017; Pandey, 2017), and were more likely to be uneducated (Marphatia et al., 2020). These factors, and gendered socio-cultural norms restricting women's physical mobility outside of the home, mean that women typically have low levels of agency and decision-making power (Gram et al., 2017; Harris-Fry et al., 2018; Morrison et al., 2018). The main livelihood of this population is subsistence farming (rice, wheat, pulses), with the majority of households purchasing some food items from local markets, or 'bazaars' (Saville, Manandhar \& Wells, 2020).

\section{Data}

\section{Outcome variables}

For our first outcome variable, women's 'early marriage,' we use several different age groupings since the majority of our sample (87\%) married below the UN stipulated minimum age of 18 years. In Nepal, the legal minimum age at marriage is 20 years, and until recently, marriage at 18 years was possible with parental permission (His Majesty's Government of Nepal, 1963; Government of Nepal, 2017). Since our trial was conducted prior to this change in legislation, and as few women had married $\geq 20$ years, we use the minimum marriage age cut-off of 18 years as the reference group. To ensure comparability across these results, the same reference group, marrying $\geq 18$ years, is used irrespective of the age used to define early marriage. We examine the factors associated with marrying $<15$ years (hence excluding women who married between $15-18$ years), $<16$ years (hence excluding women who married between $16-18$ years), $<17$ years (hence excluding women who married between 17-18 years), and $<18$ years of age (includes the full sample). In other words, each of the models above the $<15$ years has the lower group nested within it, but excludes the higher group up to 18 years. Figure 1 illustrates our approach. 
282

283

284

285

286

287

288

289

290

291

292

293

294

295

296

297

298

299

300

301

302

303

304

305

306

307

308

309

310

311

312

313

314

315

316

317

318

319

320

321

322

323

324

325

326

327
Figure 1 here

Our second outcome variable, women 'being uneducated,' is coded as any formal education ( $\geq 1$ year) vs no education ( 0 years). We use this cut-off because two-thirds of our sample have never been to school.

\section{Exposures}

Our primary exposure is the score of assets measured in the women's natal household. The natal household asset score is categorized in quintiles, from 1 (poorest) to 5 (richest). This assessment of assets is widely used by national representative surveys, including in our study context (MOHP, New ERA \& ICF International, 2017). These assets represent relatively stable markers of wealth, relating to the structure of the home or ownership of consumer goods that require significant financial outlay. They are assumed already to exist before a daughter marries. However, in contrast to the 12-asset score that has been used in previous studies on this population (Saville et al., 2016; MOHP, New ERA \& ICF International, 2017; Sah, 2018), we use an 8-asset score. We exclude goods such as color television, motorbike, and computer because they could have been acquired after the daughter had married, especially if there was a long time-gap between marriage and when the assets were measured. We also exclude agrarian land-holding from the score, because we want to investigate whether its association with women's early marriage and lack of education is independent to that of assets.

We therefore construct our score of assets from eight variables using principal component analysis (Vyas and Kumaranayake 2006). The first principal component has positive factor loadings for all eight variables and accounts for $36.7 \%$ of the variability, compared to $13.2 \%$ for the second principal component. Thus we use the first principal component as the marker of natal household wealth. The eight variables contributing the highest factor loadings to the first principal component, listed in order of decreasing size (weight shown in parenthesis), are: wall (0.457), roofing $(0.442)$ and flooring $(0.423)$ materials, toilet facilities $(0.412)$, number of rooms used for sleeping in the house $(0.317)$, access to electricity $(0.242)$, drinking water source $(0.227)$ and non-biomass cooking fuel use (0.188).

Our second key exposure is women's educational attainment. Education is coded according to the Nepalese education system: none; primary (1-5 years); lower-secondary (6-8 years); or secondary or higher ( $\geq 9$ years) (Ministry of Education Nepal, 2016).

We also include broader markers of household socio-economic disadvantage. Agrarian landholding is coded as none, 0.01 to $0.5,0.51$ to 0.99 and $\geq 1$ hectare. A household's spatial niche, defined by its geographic location, is categorized by accessibility to large markets, known as 'bazaars,' using the normal form of transport, quantified in terms of time ( $<30$ minutes; 30-59 minutes; 60-89 minutes; or $\geq 90$ minutes). Large bazaars may be a proxy for access to broader social connections, resources, larger health facilities and schools. Four groups describe caste affiliation: disadvantaged castes are coded into two separate groups: Dalit and Muslim, middle combines Janjati and various Madhesi castes, and advantaged combines Yadav and Brahmin. We do not include religion as the disadvantaged caste variable already examines the Muslim faith separately, and all other groups refer to the Hindu faith.

PeerJ reviewing PDF | (2021:07:63393:1:0:NEW 21 Sep 2021) 
328 The women in our sample range from age 18 to age 39 years. Access to education and social

329 norms may have changed in the 20 years between the oldest and youngest generations. We

330 therefore control for women's age to capture the ways in which secular changes in societal

331 norms may impact marriage age and education patterns.

332

333

\section{Statistical methods}

334 We first test for bias in the characteristics of women with assets measured in their natal versus

335

336

337

338

339

340

341

342

343

344

345

346

347

348

349 marital households using chi-squared tests (categorical variables) and non-parametric $k$-sample analysis of variance (Kruskal-Wallis test; continuous variables). We also test for differences in individual assets by asset quintile level using chi-squared tests (categorical variables) and ANOVA (reporting the mean and standard deviation, SD). Given the skewed distribution of women's age, we report the median (and interquartile range, IQR) values in completed integer years. A heat table examines the distribution of women by education level and natal household wealth quintiles. We use SPSS 26 to conduct these analyses (IBM Corp., Armonk, NY). Using R library tidyverse and ggplot2, we create boxplots to stratify the association of women's marriage age with their education by natal household asset quintiles (Wickham, 2016; Wickham et al., 2019).

We fit logistic mixed-effects models with a random effect on the intercept accounting for withincluster variability. If $i$ denotes individuals nested within geographic clusters, the equation for a general regression model of this form with $p$ covariates, and random effects in the intercept $\left(u_{i 0}\right)$ and in one covariate $\left(u_{i 1}\right)$ is shown below. Logit is the log-odds function, defined as $\ln \left(\frac{\pi_{i}}{1-\pi_{i}}\right)$, where $\pi_{i}$ is the conditional probability that the binary outcome variable $Y_{i}$ equals one divided by the probability that it equals zero. $\beta_{0}$ is the intercept (constant term) and $\beta_{1}$ is the slope, or coefficient estimate describing the relationship between the outcome and the predictor variable $X_{1}$. The index $j$ denotes variables, respectively, and the residual error term, $\varepsilon_{i}$ is assumed to be Normally distributed with mean 0 and variance $\sigma^{2}$, whilst the random effects are assumed to follow a bivariate Normal distribution with mean $(0,0)$ and variance-covariance matrix $\left(\begin{array}{cc}\vartheta_{0}^{2} & \tau_{01} \\ \tau_{01} & \vartheta_{1}^{2}\end{array}\right)$, independently of $\varepsilon$.

359

Our logistic mixed-effects model, shown below differs from the usual fixed-effects model in that it includes random effects accounting for unobserved heterogeneity due to the 80 geographic

360

361

362 clusters of the trial:

$$
\operatorname{logit}=\ln (\text { odds })=\ln \left(\frac{\pi_{i}}{1-\pi_{i}}\right)=\left(\beta_{0}+u_{i 0}\right)+\left(\beta_{1}+u_{i 1}\right) x_{i 1}+\sum_{j=2}^{p} \beta_{j} x_{i j}+\varepsilon_{i}
$$

Our models estimate the probabilities, derived from adjusted Odds Ratios (aORs) with 95\% Confidence Interval (CI) of women (a) marrying $<15,<16<17$ or $<18$ years, and (b) being uneducated. Models of the factors associated with being uneducated do not include marriage age because it is not appropriate to use a factor which occurred at time B (marriage age) to predict something earlier at time A (never starting school). All of the models control for women's age (potential cohort effect), which, when included together with their age at marriage effectively 
370 accounts for the time-gap between when they married and their current age (when they were

371 recruited into the trial). Since our interest is in understanding whether poverty (defined relative

372 to the richest quintile) is associated with early marriage, the reference group is set as the highest

373 category across variables, hence: richest asset quintile, secondary education, agrarian land-

374 holding of $\geq 1$ hectare and advantaged caste. Living near to the biggest bazaar ( $<30$ minutes) is

375

376

377

378

379

380

381

382

383

384

385

386

387

388

389

390

391

392 set as the reference group because we assume it is a proxy for better access to school and other resources.

We evaluate goodness-of-fit using the Nakagawa-Schielzeth marginal $R^{2}$ which measures the percentage of variance explained by the model's fixed effects (Nakagawa \& Schielzeth, 2013). Logistic mixed-effects models are fitted using the R library lme 4 (Bates et al., 2014).

We adjust for trial arm because women from natal households were more likely to enroll in the cash and food interventions. However, since the trial recruited women who were already married and currently pregnant, the intervention could not have influenced marriage age or education (which typically is ended before/once women marry). Moreover, assets were measured before the trial was conducted, so the cash supplementation arm could not have changed their value. As the trial arm was not associated with our outcomes, we do not report the findings, although it is still controlled for in our analyses.

We conduct a sensitivity analysis to examine if the association between poverty and our outcomes change if we apply looser selection criteria, by including all of the women measured in their natal household $(n=3,379)$ regardless of their age. While this introduces the possibility of distortion due to selection bias (as discussed above), it nevertheless allows us to test our hypotheses with a much bigger sample of women.

395

396

397

\section{Results}

398 Married pregnant women were interviewed in the home in which they were residing at the time of recruitment into the trial. Of the 25,090 women recruited into our study, we first exclude 408

400

401

402

403

404

405

406

407

408

409

410

411

412

413

414

415 women with multiple pregnancies during the trial to ensure they are not double counted in our analysis. Second, of the remaining 24,682 women (raw data in Data S1 contains this sample), we exclude 3,968 women who had no data on the household in which assets were measured and a further 17,335 women who were interviewed in their marital home. This leaves 3,379 women whose assets and other characteristics were measured in their natal household.

Third, we exclude 947 women aged $<18$ years because they would not have had the chance of marrying at older ages, nor adequate time to finish greater levels of education before marrying. The relationship between wealth, education and marriage age is not likely to be distorted due to the selection bias of recruiting only married pregnant women into our study. In the context of our study, women are very unlikely to continue their education after marriage (Sekine \& Hodgkin, 2017). The vast majority of married women are also likely to have children, and it is common in Nepal get pregnant in the first two years after marriage (MacQuarrie, 2016; Marphatia et al., 2020). Our analysis therefore includes 2,432 women aged 18-39 years measured in their natal households, representing $9.7 \%$ of the total 25,090 women recruited into the trial. 
416 Table S1 examines whether the characteristics of the women measured in their natal homes are 417 different to those measured in their marital homes. This enables us to identify potential bias in 418 our sample which may result in these two groups of women having a different relationship 419 between wealth and marriage age. A direct comparison between these women is not possible 420 because we do not know the socio-economic background of the natal households of the women

421

422

423

424

425

426

427

428

429

430

431

432

433

434

435

436

437

438

439

440

441

442

443

444

445

446

447

448

449

450

451

452

453

454

455

456

457

458

459

460

461

462 who were measured in their marital home.

In comparison to women who were measured in their marital home, those measured in their natal homes are younger, have been married for less time, but at an older age. A greater proportion of women measured in their natal households are from disadvantaged castes, residing further away from big bazaars, and in the trial's cash and food supplementation arms. It is possible that the trial may have incentivised women to return to their natal homes to access these incentives. Women did not differ in their education level, age at first pregnancy, or household asset score. Whilst these results show that women who went to their natal homes during pregnancy are different than those who stayed in their marital homes, the differences are small. The women in our sample still represent an important sub-group of women with rare data on the socioeconomic characteristics of their natal homes.

\section{Description of sample}

Table 1 describes our sample of women aged 18-39 years. Women are of median age 21 years (IQR 4) and have been married for a median of 5 years (IQR 5). Marriage is typically early among women (median 15 years, IQR 3 ), and $18 \%$ married $\geq 18$ years. Two-thirds of the women are uneducated, $39 \%$ are from natal households without agrarian land and disadvantaged castes respectively, and 29\% live far from large bazaars.

\section{Table 1 here}

The heat table shows the overall number of women by their education level and natal household wealth quintiles (Table 2). Green shaded areas indicate low numbers and red shaded numbers the highest numbers. Within the whole sample, uneducated women are most likely to come from poorer natal households, and the more educated women are more likely to come from richer households. However, since two-thirds of our sample is uneducated, there is substantial variability by wealth that is independent of education.

\section{Table 2 here}

Figure 2 illustrates the association of women's marriage age with their education level, stratified by natal household asset quintiles. Overall, within each wealth group, women with more education marry later. The level of education associated with delayed marriage differs slightly across wealth groups. Interestingly, even in the poorest and poor wealth groups, the median age at marriage is two years later among women with $\geq 6$ years of education than among those with no or less education.

\section{Figure 2 here}

\section{Hypothesis 1}


463 Hypothesis 1 investigates the association of the natal household asset score with the odds of 464 early marriage, using each of the four age-definitions of early marriage. Across Models 1-4 in 465 Table 3, there is no evidence of a cohort effect, which may be explained by the relatively narrow

466

467

468

469

470

471

472

473

474

475

476

477

478

479

480

481

482

483

484

485

486

487

488

489

490

491

492

493

494

495

496

497

498

499

500

501

502

503

504

505

506

507

508

age range of our sample. Relative to the richest asset quintile, women from all other asset quintiles have an elevated risk of early marriage, regardless of the age threshold used to define 'early'. However, there is little consistent gradient between the coefficients of the poorest four asset groups, indicating that the main difference in marriage age is between the richest and the rest (this is confirmed by analyses using other asset groups as reference (not shown)). The variance in marriage age explained by the four models is very low: $5.0 \%, 3.2 \%, 2.8 \%$ and $2.1 \%$. These results do not support our first hypothesis, that natal household poverty is associated with the likelihood of marrying at different early ages.

\section{Table 3 here}

\section{Hypothesis 2}

Hypothesis 2 investigates the association of broader socio-economic factors with the likelihood of marrying early as defined by the four different age thresholds. With the exception of Model 4, age is not a significant factor associated with early marriage, indicating the absence of a cohort effect (Table 4). Model 4 shows that older women are less likely to marry $<18$ years than $\geq 18$ years, which is perhaps surprising: we expected that further in the past (older women) prevailing socio-cultural norms might have more strongly favoured earlier marriage. This cohort effect only emerges when education is controlled for in the analysis, which suggests that it is connected to difference in the availability of, and attitudes towards, education over time. It is also possible that this cohort effect emerges because in the past, high levels of education were rarer, and therefore more tightly associated with delayed marriage compared to more recent times, when education is more widely available to the younger women in our sample.

Across Models 1-4 in Table 4, the asset score is no longer associated with early marriage when women's education is included. The effect of lower wealth appears therefore to be channelled through women's education, which is a better predictor of early marriage in this population.

There is a clear education gradient in the likelihood of marrying early, however 'early' is defined. Relative to secondary education, all other education levels have an elevated risk of early marriage, with uneducated women having a substantially greater risk. The magnitude of effect of education also decreases with each additional year used to define early marriage, suggesting that education tends to increase with age, but assets do not. Neither land, caste nor geographic location are associated with any of the marriage age models when women's education is controlled.

Compared to Table 3, these models are almost three times better at explaining the variance across the four marriage age groups: $23.5 \%, 16.4 \%, 13.1 \%$ and $10.6 \%$. These results support our second hypothesis, that women's lower educational attainment, independent of natal household poverty and broader markers of socio-economic disadvantage, is associated with early marriage, whatever the age threshold used to define 'early'.

\section{Table 4 here}




\section{Hypothesis 3}

510 Hypothesis 3 investigates whether amongst the uneducated women $(n=1,610)$, poverty,

511 independent of broader markers of socio-economic disadvantage, is associated with early

512 marriage at different ages. Results show no cohort effect, nor any association with wealth (Table

5135 Models 1-4), suggesting that the uneducated women who marry early are not systematically

514 more or less wealthy compared to those marrying $\geq 18$ years. There is also no association

515 between broader socio-economic factors and early marriage, whatever age threshold is used to

516 define early marriage (Table 6 Models 1-4).

517

518

519

520

521

522

523

524

525

526

527

528

529

530

531

532

533

534

535

536

537

538

539

540

541

542

543

544

545

546

547

548

549

550

551

552

553

554

\section{Tables 5 \& 6 here}

In Table 5, models explain $6.2 \%, 5.4 \%, 5.0 \%$ and $5.0 \%$ of the variance in women marrying $<15$, $<16,<17$ years and $<18$ years respectively. In Table 6, models explain slightly more of the variance in early marriage across the age groups $7.1 \%, 6.6 \%, 5.8 \%$ and $6.0 \%$. In comparison to models in Table 4 for women with all educational levels, those in Table 6 explain less variance. The total absence of women's education in these models is likely to explain this difference. These results do not support our third hypothesis, that among uneducated women, poverty, independent of broader markers of socio-economic disadvantage, is associated with early marriage at different ages.

\section{Hypothesis 4}

Hypothesis 4 investigates whether poverty, independent of broader socio-economic factors, is associated with women being uneducated. Across the two models in Table 7, older women are more likely to be uneducated, reflecting the increase in the availability and acceptability of education for girls over the 20-year period during which our sample was maturing.

Model 1 shows a clear wealth gradient in the likelihood of being uneducated. Relative to the richest quintile, all other asset quintiles have an elevated risk of being uneducated, with the poorest quintile having a substantially greater risk. Model 2 finds a similar pattern after inclusion of broader socio-economic factors. In comparison to Model 1, the magnitude of effect of the first wealth quintile is weaker, that of the mid quintile only slightly weaker, and unchanged in the two richest quintiles. Relative to higher agrarian land-holding, both none and some land-holding are associated with being uneducated. Relative to the advantaged caste, the two disadvantaged castes are associated with being uneducated, with the risk substantially greater for the Muslim caste. Relative to living near a big bazaar, living 30-59 minutes away, but not further distances, is marginally associated with being uneducated.

Model 1 explains $21.0 \%$ of the variance in women's education, which is lower than Model 2, which explains $36.3 \%$ of the variance. These results support our fourth hypothesis, that poverty, independent of broader socio-economic factors, is associated with women being uneducated.

\section{Table 7 here}

\section{Supplementary analysis}

A potential reason why poverty may not be associated with women's early marriage, irrespective of the age used to define early marriage, could be that the individual assets owned by households do not actually differ between the wealth quintiles. Table $\mathbf{S 2}$ shows, however, that there is 
555

556

557

558

559

560

561

562

563

564

565

566

567

568

569

570

571

572

573

574

575

576

577

578

579

580

581

582

583

584

585

586

587

588

589

590

591

592

593

594

595

596

597

598

599

600

substantial variability across the eight individual assets used to produce our composite asset score using PCA. We also include land-holding in this analysis because it is another marker of wealth in our primarily agrarian population. These individual assets and land ownership matter for daily life and indicate the household's purchasing power. Our results show that asset ownership does indeed differ by wealth levels, nevertheless our analyses described above show that wealth in itself is not associated with women's early marriage in this population.

Given the selection bias in our study of recruiting young, already married and pregnant women, we have restricted the analyses described above to women aged $\geq 18$ years only. With the exception of the association of age, our results are nonetheless similar if we include the full sample of women aged 12-39 years $(n=3,379)$ (Tables S3-S7). The significance of the age variable in these models is a product of the selection effects (as discussed above), and not a cohort effect.

\section{Discussion}

Our study aims to contribute robust evidence on the association between natal household wealth and early marriage. Our results show that if we measure assets in the natal household, we do not support the conventional hypothesis that household poverty is associated with women's early marriage. In our population, relative to the richest households, all other asset level households have an elevated risk of marrying early, and the poorest households do not stand out. Additional analysis shows substantial variability in individual assets and land-holding by asset quintiles, but that wealth in itself is not directly associated with women's early marriage. Our results are somewhat similar to the only other study from Nepal which measured natal household wealth and also did not find the poorest households married daughters the earliest; rather, daughters from the second poorest households were more likely to marry early (Bajracharya \& Amin, 2012). In contrast, studies from India have either found that poorer households are most likely to marry their daughters early (Singh \& Espinoza Revollo, 2016), or that wealth of the natal household is not associated with early marriage (Marphatia et al., 2021b). Overall, these inconsistent results suggest that we still have a poor understanding of how wealth may shape the timing of women's marriage.

We also found that women's education displaces wealth as a predictor of early marriage, whatever age is used to define early marriage. Relative to secondary-schooled women, women in all other education categories have a higher risk of marrying early. However, there is also a clear gradient, with uneducated women showing the greatest likelihood of early marriage. The association of high wealth with reduced risk of early marriage therefore works through education, and more generally it is women's education level that is directly related to their marriage age. This finding supports the well-established association between women's lower education and their early marriage (Raj et al., 2014; Delprato et al., 2015; Sekine \& Hodgkin, 2017; Marphatia et al., 2020; Scott et al., 2021).

Nonetheless, we found that even in combination, household wealth and women's educational attainment still explain a low proportion of the variance in the likelihood of early marriage models, suggesting that other factors largely drive marriage decisions in this population. Among uneducated women, neither poverty nor broader markers of household disadvantage are associated with early marriage, however 'early' is defined. Since there was no association of 
601 household wealth with early marriage among uneducated women, we suggest that socio-cultural

602

603

604

605

606

607

608

609

610

611

612

613

614

615

616

617

618

619

620

621

622

623

624

625

626

627

628

629

630

631

632

633

634

635

636

637

638

639

640

641

642

643

644

645

646 norms that are unconnected with education may be the primary driver of early marriage. For example, if girls are not in school, their primary role in society may be that of a daughter, wife and mother. However, the differences in the age of marriage within uneducated women may also relate to other factors unmeasured by our study.

Where poverty appears to really matter is for the level of education achieved by women, potentially because of the costs associated with schooling, as reported in other studies (Verma, Sinha \& Khanna, 2013; Chaudhuri, 2015; Samuels et al., 2017). We found that independent of poverty, both landless and lower agrarian land-holding families are less likely to send their daughters to school. The lack of land may reflect chronic food insecurity, whereas households with some land may prefer daughters to contribute to family income through working on the farm, rather than attending school. Whereas landlessness and the related food insecurity have been associated with both lower schooling and early marriage of girls (Moock \& Leslie, 1986; UNICEF, 2014), our study found that it predicted less schooling, but not early marriage.

However, as with wealth, the association of lower agrarian land-holding and early marriage may work through education, in that if girls are not in school, marrying them early may decrease household food and financial burdens (Maharjan et al., 2012; Human Rights Watch, 2016; Samuels et al., 2017).

Like other studies, we also find that disadvantaged castes, especially of the Muslim faith, tend to have lower education (Stash \& Hannum, 2001; Sah, 2018; Devkota, Eklund \& Wagle, 2020), but this factor was not associated with early marriage. Caste affiliation may be a maker of overall status in society, and therefore act as another marker of access to resources and life opportunities. We find no evidence of the natal household's proximity to big bazaars mattering for early marriage, and there is also no clear relationship between distance from bazaar and lack of education.

\section{Implications}

Our results have implications for research, policy and practice. First, there is an urgent need for informative objective data measuring wealth in women's natal households, ideally before they marry, and also in women's marital households, ideally at the time of their marriage. This approach would provide much needed evidence on whether natal household poverty is indeed associated with the likelihood of early marriage and whether women marry into households of similar wealth levels.

These data-related issues, and in particular the inadequate understanding of the association of wealth and marriage age, may partly explain the inconsistent results of interventions targeting poverty as the main driver of early marriage. A recent systematic review found conditional cash transfers (CCTs) to keep girls in school were more effective in delaying marriage than those directly targeting delayed marriage or poverty (Malhotra \& Elnakib, 2021). In Bangladesh, CCTs supported girls to stay in school for longer, but delayed marriage for only the youngest girls (aged 12-14 years) living in the poorest district (Amin, 2007). In India, another intervention gave CCTs to parents if their daughters had reached the age of 18 years unmarried. Compared to a control group, the girls who participated in this intervention stayed in school up to grade eight, and were in fact more likely to marry just after the 18 year cut-off stipulated by the intervention

Peer] reviewing PDF | (2021:07:63393:1:0:NEW 21 Sep 2021) 
647 (Nanda et al., 2015). In both interventions, the cash transfers was primarily used by parents to 648 pay the higher cost of dowries demanded by marital households for older, more educated girls 649 (Amin, 2007; Nanda et al., 2015).

650

651

Second, we need to better understand the different factors increasing the risk of marrying at different ages, for women of different education levels. Reducing the costs of schooling (e.g.

653 fees, learning materials, offering scholarships) and improving the quality of education may help

654

655 girls to stay in school for longer and also delay marriage, thereby achieving several of the Sustainable Development Goals (Muchomba, 2021). Further research is needed to understand

656

657 whether the expansion of free state provision of secondary education would have a sustained impact on delaying marriage. However, any school-based efforts will miss the girls who never

658

659

660

661 went to school in the first place or have already dropped out and married.

Third, there needs to be a collective shift in societal gendered norms and the value attributed to girls and women in society (Maertens, 2013; Bicchieri, Jiang \& Lindemans, 2014; Marphatia,

662

663

664

665 Amable \& Reid, 2017). Changing norms is difficult and slow, as shown by social interventions that did not succeed in delaying marriage age in India (Prakash et al., 2019; Ramanaik et al., 2020). Moreover, in populations where women marry very early, it may initially be more realistic to delay marriage by one year at a time. In our study, this would mean first delaying

666

667

668

669

670

671 marriage from 15 to 16 years, and then from 16 to 17 years. 'Nudging' populations towards a slightly later marriage age for women may therefore lead to more substantial secular changes over time. Whilst this may sit uncomfortably with the human rights constituencies advocating for the 18-year minimum marriage age, ignoring these practiced norms may render us even further from the common goal of delaying marriage overall (Schaffnit, Urassa \& Lawson, 2019). Delaying marriage, even by one year, will inevitably delay the age at first child bearing. Early marriage must therefore be seen as a critical concern for public health (Marphatia, Amable \&

673

674

675 Reid, 2017).

676 Our study has some limitations. With cross-sectional data, we can only investigate associations and not causality. Although we include education in early marriage models, like other studies, we do not know the direction of this association. We did not have data on the amount of dowry paid by women's natal household, nor whether it accelerated the timing of their marriage. Our

680 study involved only married pregnant women and we found that women measured in their natal homes during pregnancy differed from those who remain in their marital homes. However, these

682

683

684

685

686

687

688

689

690

691

692 differences were small. As we do not have matching data on pregnant women in their marital homes we cannot explore the other ways in which they may differ. In our population, women are also very unlikely to continue their education after marriage, and the vast majority of married women are likely to have children, and it is common in Nepal get pregnant in the first two years after marriage. Our asset score was measured in the natal household after, and not at, marriage. To address this, our asset score excluded items which could have been purchased after marriage. Despite these limitations, our study benefited from a large sample size and the unique data on several different socio-economic variables as well as women's education. The associations between poverty, education and marriage age, and poverty and lack of education identified in our study are likely to be widely applicable, especially to similar Madhesi populations living around the bordering regions of India and Nepal. 
693

694

695

696

697

698

699

700

701

702

703

704

705

706

707

708

709

710

711

712

713

\section{4}

715

716

717

718

719

720

721

722

723

724

725

726

727

728

729

730

731

732

733

734

735

\section{Conclusion}

Our study is unique in having objective data on assets and broader markers of disadvantage measured in women's natal household. These data enable us to conduct robust and appropriate investigations of the association of natal household wealth with early marriage, using different age thresholds to define 'early'. We also investigate the association of education with the likelihood of early marriage, and whether poverty is associated with early marriage in uneducated women who comprise two-thirds of our sample. Finally, we investigate whether poverty is associated with the likelihood of women having no formal education. Whilst we do not find that natal household poverty predicted early marriage in rural lowland Nepal, further research is required in other populations to establish whether this association is apparent more generally.

\section{Acknowledgements}

We thank the women and their families for participating in the trial, and for allowing us to measure their newborns. The Public Health Offices of Dhanusha and Mahottari Districts in Nepal supported implementation of the trial. We also thank Mother and Infant Research Activities (MIRA, Nepal) staff for data collection, and the UCL Institute for Global Health team for their support (see Saville et al., 2018 for details).

\section{Data availability statement}

Raw data are available for the purposes of replicating the results in this paper (Data S1). Contact Dr Naomi Saville at n.saville@ucl.ac.uk for further information.

\section{References}

Allendorf K, Thornton A. 2015. Caste and Choice: The Influence of Developmental Idealism on Marriage Behavior. American Journal of Sociology 121:243-287. DOI: 10.1086/681968.

Amin S. 2007. Empowering adolescent girls in rural Bangladesh: Kishori Abhijan. New York: USA: Population Council. Available at https://knowledgecommons.popcouncil.org/departments_sbsr-pgy/811/ (accessed 20 April 2021).

Aryal TR. 2007. Age at first marriage in Nepal: differentials and determinants. Journal of Biosocial Science 39:693-706. DOI: 10.1017/S0021932006001775.

Ayral K. 2014. A Steep Climb Uphill: Does geography and environment create barriers to secondary-aged girls' equitable access to, and participation in education in remote areas of Nepal? Unpublished MSc Thesis. London: UK: London South Bank University.

Bajracharya A, Amin S. 2012. Poverty, marriage timing, and transitions to adulthood in Nepal. Studies in family planning 43:79-92. DOI: https://doi.org/10.1111/j.17284465.2012.00307.x.

Bates D, Mächler M, Bolker B, Walker S. 2014. Fitting linear mixed-effects models using lme4. Journal of Statistical Software 67:1-48. DOI: doi:10.18637/jss.v067.i01. 
736

737

738

739

740

741

742

743

744

745

746

747

748

749

750

751

752

753

754

755

756

757

758

759

760

761

762

763

764

765

766

767

768

769

770

771

772

773

774

775

776

777

778

779

780

Bates L, Maselko J, Schuler R. 2007. Women's Education and the Timing of Marriage and Childbearing in the Next Generation: Evidence from Rural Bangladesh. Studies in Family Planning 38:101-112. DOI: 10.1111/j.1728-4465.2007.00121.x.

Bicchieri C, Jiang T, Lindemans J. 2014. A Social Norms Perspective on Child Marriage: The General Framework. Draft report for UNICEF. Philadelphia: USA: Philadelphia:

Behavioral Ethics Lab, University of Pennsylvania. Available at https://repository.upenn.edu/cgi/viewcontent.cgi?article=1012\&context=pennsong (accessed 20 April 2021).

Boyden J. 2013. 'We're not going to suffer like this in the mud': educational aspirations, social mobility and independent child migration among populations living in poverty. Compare: A Journal of Comparative and International Education 43:580-600. DOI: 10.1080/03057925.2013.821317.

Caldwell J, Reddy P, Caldwell P. 1983. The causes of marriage change in South India. Population Studies 37:343-361. DOI: 0.1080/00324728.1983.10408866.

Chari AV, Heath R, Maertens A, Fatima F. 2017. The causal effect of maternal age at marriage on child wellbeing: Evidence from India. Journal of Development Economics 127:42-55. DOI: $10.1016 /$ j.jdeveco.2017.02.002.

Chaudhuri ER. 2015. Unrecognised Sexual Abuse and Exploitation of Children in Child, Early and Forced Marriage. ECPAT International, Plan International. Available at https://www.ecpat.org/wp-content/uploads/2016/04/Child\%20Marriage_ENG.pdf (accessed 15 April 2021).

Clarke KL. 2013. Tension in the Terai: exploring maternal mental health in the perinatal period and interventions to improve it in Dhanusha district, Nepal. Unpublished PhD Thesis. London: UK: UCL Institute for Global Health.

Delprato M, Akyeampong K, Sabates R, Hernandez-Fernandez J. 2015. On the impact of early marriage on schooling outcomes in Sub-Saharan Africa and South West Asia. International Journal of Educational Development 44:42-55. DOI: 10.1016/j.ijedudev.2015.06.001.

Devkota S, Eklund J, Wagle U. 2020. Caste/ethnic differences in school dropout among 5-20year olds in Nepal. Educational Review:1-20. DOI: 10.1080/00131911.2020.1793734.

Devkota SC, Upadhyay MP. 2015. What Factors Change Education Inequality in Nepal? Journal of Human Development and Capabilities 16:287-308. DOI: 10.1080/19452829.2015.1029882.

Fafchamps M, Shilpi F. 2011. Education, Preferences, and Household Welfare. Oxford: UK: CSAE. Available at https://core.ac.uk/download/pdf/6265606.pdf (accessed 25 April 2021).

Fall CHD, Osmond C, Haazen DS, Sachdev HS, Victora C, Martorell R, Stein AD, Adair L, Norris S, Richter LM. 2016. Disadvantages of having an adolescent mother. The Lancet Global Health 4:e787-e788. DOI: 10.1016/S2214-109X(16)30263-7.

Finlay JE, Özaltin E, Canning D. 2011. The association of maternal age with infant mortality, child anthropometric failure, diarrhoea and anaemia for first births: evidence from 55 low- and middle-income countries. BMJ Open 1:e000226. DOI: 10.1136/bmjopen-2011000226.

Fisher B, Naidoo R. 2016. The Geography of Gender Inequality. PLOS ONE 11:e0145778. DOI: 10.1371/journal.pone.0145778.

Peer) reviewing PDF | (2021:07:63393:1:0:NEW 21 Sep 2021) 
781

782

783

784

785

786

787

788

789

790

791

792

793

794

795

796

797

798

799

800

801

802

803

804

805

806

807

808

809

810

811

812

813

814

815

816

817

818

819

820

821

822

823

824

825

826

Ganchimeg T, Ota E, Morisaki N, Laopaiboon M, Lumbiganon P, Zhang J, Yamdamsuren B, Temmerman M, Say L, Tunçalp Ö, Vogel J, Souza J, Mori R, on behalf of the WHO Multicountry Survey on Maternal Newborn Health Research Network. 2014. Pregnancy and childbirth outcomes among adolescent mothers: A World Health Organization multicountry study. BJOG: An International Journal of Obstetrics \& Gynaecology 121:40-48. DOI: 10.1111/1471-0528.12630.

Godha D, Hotchkiss D, Gage A. 2013. Association Between Child Marriage and Reproductive Health Outcomes and Service Utilization: A Multi-Country Study From South Asia. Journal of Adolescent Health 52:552-558. DOI: 10.1016/j.jadohealth.2013.01.021.

Goli S, Rammohan A, Singh D. 2015. The Effect of Early Marriages and Early Childbearing on Women's Nutritional Status in India. Maternal and Child Health Journal 19:1864-1880. DOI: $10.1007 / \mathrm{s} 10995-015-1700-7$.

Government of Nepal. 2017. The National Civil (Code) Act, 2017 (2074) http://www.moljpa.gov.np/en/wp-content/uploads/2018/12/Civil-code.pdf(accessed 15 September 2021).

Gram L, Morrison J, Sharma N, Shrestha B, Manandhar D, Costello A, Saville N, SkordisWorrall J. 2017. Validating an Agency-based Tool for Measuring Women's Empowerment in a Complex Public Health Trial in Rural Nepal. Journal of human development and capabilities 18:107-135. DOI: https://doi.org/10.1080/19452829.2016.1251403.

Guragain AM, Paudel BK, Lim A, Choonpradub C. 2017. Adolescent Marriage in Nepal: A Subregional Level Analysis. Marriage \& Family Review 53:307-319. DOI: https://doi.org/10.1080/01494929.2016.1157560.

Harris-Fry HA, Paudel P, Shrestha N, Harrisson T, Beard BJ, Jha S, Shrestha BP, Manandhar DS, Costello AM, Cortina-Borja M. 2018. Status and determinants of intra-household food allocation in rural Nepal. European Journal of Clinical Nutrition:1. DOI: https://doi.org/10.1038/s41430-017-0063-0.

His Majesty's Government of Nepal. 1963. The Muluki Ain (General Code). Kathmandu: Nepal: His Majesty's Government of Nepal. Available at https://www.lawcommission.gov.np/en/wp-content/uploads/2018/10/muluki-ain-generalcode-2020.pdf (accessed 4 April 2021).

Hodgkinson K. 2016. Understanding and addressing child marriage A scoping study of available academic and programmatic literature for the HER CHOICE Alliance. Amsterdam:Netherlands: University of Amsterdam. Available at https://www.girlsnotbrides.org/learning-resources/resource-centre/understanding-andaddressing-child-marriage-a-scoping-study-of-available-academic-and-programmaticliterature-for-the-her-choice-alliance/ (accessed 19 May 2021).

Human Rights Watch. 2016. Our Time to Sing and Play: Child marriage in Nepal. USA: Human Rights Watch. Available at https://www.hrw.org/sites/default/files/report_pdf/nepal0816_web.pdf (accessed 26 April 2021).

ICRW. 2006. Child marriage and poverty. Washington DC: USA: ICRW. Available at https://www.icrw.org/files/images/Child-Marriage-Fact-Sheet-Poverty.pdf (accessed 19 May 2021).

Jackson C. 2012. Introduction: marriage, gender relations and social change. The Journal of Development Studies 48:1-9. DOI: https://doi.org/10.1080/00220388.2011.629653.

Peer) reviewing PDF | (2021:07:63393:1:0:NEW 21 Sep 2021) 
827

828

829

830

831

832

833

834

835

836

837

838

839

840

841

842

843

844

845

846

847

848

849

850

851

852

853

854

855

856

857

858

859

860

861

862

863

864

865

866

867

868

869

870
Jamison T, Lockheed M. 1987. Participation in Schooling: Determinants and Learning Outcomes in Nepal. Economic Development and Cultural Change 35:279-306.

Karim N, Greene M, Picard M. 2016. The Cultural Context of Child Marriage in Nepal and Bangladesh: Findings from CARE's Tipping Point Project Community Participatory Analysis. Geneva: Switzerland: Care. Available at https://www.girlsnotbrides.org/learning-resources/resource-centre/care-tipping-pointproject-nepal-bangladesh/ (accessed 19 May 2021).

MacQuarrie K. 2016. Marriage and Fertility Dynamics: The Influence of Marriage Age on the Timing of First Birth and Birth-Spacing. Rockville: MD: ICF International.

MacQuarrie KLD, Juan C. 2019. Trends and factors associated with child marriage in four Asian countries. Gates Open Research 3:1467. DOI: 10.12688/gatesopenres.13021.1.

Maertens A. 2011. Does education pay off? Subjective expectations on education in rural India. Economic and Political Weekly XLVI:58-63. DOI: https://www.jstor.org/stable/41151840.

Maertens A. 2013. Social Norms and Aspirations: Age of Marriage and Education in Rural India. World Development 47:1-15. DOI: 10.1016/j.worlddev.2013.01.027.

Maharjan RK, Karki KB, Shakya TM, Aryal B. 2012. Child marriage in Nepal: Research report. Kathmandu: Nepal: Plan Nepal, Save the Children, World Vision International Nepal. Available at https:/www.wvi.org/sites/default/files/Child\%20Marriage\%20in\%20Nepal\%20Report.pdf (accessed 20 April 2021).

Maharjan S, Sah RK. 2012. Madheshi Women in Nepal. In: Tewari R, Sah AP eds. The Landscape of Madhesh: Politics, society and economy of the plains. Kopundole, Lalitpur: Nepal: Nepal Madhesh Foundation,.

Malhotra A, Elnakib S. 2021. 20 Years of the Evidence Base on What Works to Prevent Child Marriage: A Systematic Review. Journal of Adolescent Health. DOI: 10.1016/j.jadohealth.2020.11.017.

Marphatia A, Amable G, Reid A. 2017. Women's Marriage Age Matters for Public Health: A review of the broader health and social implications in South Asia. Frontiers in Public Health 5:1-23. DOI: https://doi.org/10.3389/fpubh.2017.00269.

Marphatia A, Saville NM, Amable GS, Manandhar DS, Cortina-Borja M, Wells JC, Reid AM. 2020. How much education is needed to delay women's age at marriage and first pregnancy in lowland Nepal? Frontiers in Public Health 7:1-17. DOI: 10.3389/fpubh.2019.00396.

Marphatia A, Saville NM, Manandhar DS, Cortina-Borja M, Reid AM, Wells JCK. 2021a. Independent associations of women's age at marriage and first pregnancy with their height in rural lowland Nepal. American Journal of Physical Anthropology 174:103-116. DOI: https://doi.org/10.1002/ajpa.24168.

Marphatia A, Wells JCK, Reid AM, Yajnik CS. 2021b. Biosocial life-course factors associated with women's early marriage in rural India: The prospective longitudinal Pune Maternal Nutrition Study. American Journal of Biological Anthropology in press.

Ministry of Education Nepal. 2016. School Sector Development Plan, Nepal, 2016/17-2022/23. Kathmandu: Nepal: Government of Nepal, Ministry of Education. Available at https://moe.gov.np/article/1386/school-sector-development-plan-201617-202223english.html (accessed 5 May 2021).

Peer] reviewing PDF | (2021:07:63393:1:0:NEW 21 Sep 2021) 
871

872

873

874

875

876

877

878

879

880

881

882

883

884

885

886

887

888

889

890

891

892

893

894

895

896

897

898

899

900

901

902

903

904

905

906

907

908

909

910

911

912

913

914

915

MOHP, New ERA, ICF International. 2017. Nepal Demographic and Health Survey 2016. Kathmandu: Nepal: Ministry of Health and Population Nepal. Available at https://www.dhsprogram.com/pubs/pdf/fr336/fr336.pdf (accessed 16 March 2021).

Moock PR, Leslie J. 1986. Childhood malnutrition and schooling in the Terai region of Nepal. Journal of Development Economics 20:33-52. DOI: 10.1016/0304-3878(86)90004-0.

Morrison J, Dulal S, Harris-Fry H, Basnet M, Sharma N, Shrestha B, Manandhar D, Costello A, Osrin D, Saville N. 2018. Formative qualitative research to develop community-based interventions addressing low birth weight in the plains of Nepal. Public Health Nutrition 21:377-384. DOI: 10.1017/S1368980017002646.

Muchomba FM. 2021. Parents' assets and child marriage: Are mother's assets more protective than father's assets? World Development 138:105226. DOI:

10.1016/j.worlddev.2020.105226.

Nakagawa S, Schielzeth H. 2013. A general and simple method for obtaining R2 from generalized linear mixed-effects models. Methods in Ecology and Evolution 4:133-142. DOI: https://doi.org/10.1111/j.2041-210x.2012.00261.x.

Nanda P, Das P, Datta N, Lamba S. 2015. Making change with cash? Evaluation of a conditional cash transfer program to improve the status of girls in Northern India. Washington DC: USA: ICRW. Available at https://www.icrw.org/publications/making-change-with-cash/ (accessed 20 April 2021).

Pandey S. 2017. Persistent nature of child marriage among women even when it is illegal: The case of Nepal. Children and youth services review 73:242-247. DOI: https://doi.org/10.1016/j.childyouth.2016.12.021.

Pesando LM, Abufhele A. 2019. Household Determinants of Teen Marriage: Sister Effects Across Four Low- and Middle-Income Countries. Studies in Family Planning 50:113136. DOI: $10.1111 /$ sifp.12089.

Prakash R, Beattie TS, Cislaghi B, Bhattacharjee P, Javalkar P, Ramanaik S, Thalinja R, Davey C, Gafos M, Watts C, Collumbien M, Moses S, Isac S, Heise L. 2020. Changes in Family-Level Attitudes and Norms and Association with Secondary School Completion and Child Marriage Among Adolescent Girls: Results from an Exploratory Study Nested Within a Cluster-Randomised Controlled Trial in India. Prevention Science 21:10651080. DOI: 10.1007/s11121-020-01143-1.

Prakash R, Beattie TS, Javalkar P, Bhattacharjee P, Ramanaik S, Thalinja R, Murthy S, Davey C, Gafos M, Blanchard J, Watts C, Collumbien M, Moses S, Heise L, Isac S. 2019. The Samata intervention to increase secondary school completion and reduce child marriage among adolescent girls: results from a cluster-randomised control trial in India. Journal of Global Health 9. DOI: 10.7189/jogh.09.010430.

Raj A, Boehmer U. 2013. Girl Child Marriage and its Association with National Rates of HIV, Maternal Health, and Infant Mortality Across 97 Countries. Violence Against Women 19:536-551. DOI: 10.1177/1077801213487747.

Raj A, McDougal L, Rusch M. 2012. Changes in prevalence of girl child marriage in South Asia. JAMA - Journal of the American Medical Association 307:2027-2029. DOI: 10.1001/jama.2012.3497.

Raj A, McDougal L, Silverman JG, Rusch MLA. 2014. Cross-Sectional Time Series Analysis of Associations between Education and Girl Child Marriage in Bangladesh, India, Nepal and Pakistan, 1991-2011. PLOS ONE 9:e106210. DOI: 10.1371/journal.pone.0106210. 
916 Ramanaik S, Collumbien M, Pujar A, Howard-Merrill L, Cislaghi B, Prakash R, Javalkar P,

917

918

919

920

921

922

923

924

925

926

927

928

929

930

931

932

933

934

935

936

937

938

939

940

941

942

943

944

945

946

947

948

949

950

951

952

953

954

955

956

957

958

959

960
Thalinja R, Beattie T, Moses S, Isac S, Gafos M, Bhattacharjee P, Heise L. 2020. 'I have the confidence to ask': thickening agency among adolescent girls in Karnataka, South India. Culture, Health \& Sexuality 0:1-15. DOI: 10.1080/13691058.2020.1812118.

Sah N. 2012. Does dowry affect age at marriage of women. Some evidences from Terai of Nepal. Nepal Population Journal 17:55-71.

Sah N. 2018. Socio-demographic correlates of age at marriage in Nepal: An empirical analysis. Nepal Population Journal 18:1-22. DOI: https://doi.org/10.3126/npj.v18i17.26373.

Samuels F, Ghimire A, Tamang A, Uprety S. 2017. Exploring Nepali adolescents' gendered experiences and perspectives. London: UK: GAGE.

https://www.gage.odi.org/publication/nepali-adolescents-gendered-experiences-andperspectives/ (Accesssed 20 April 2021).

Saville N, Manandhar DS, Wells JC. 2020. Trial experience and data capture in the Low Birth Weight South Asia Trial, a large cluster-randomised controlled trial in lowland Nepal. London: UK: UCL Discovery. Available at https://discovery.ucl.ac.uk/id/eprint/10120616/ (accessed 20 April 2021).

Saville NM, Shrestha BP, Style S, Harris-Fry H, Beard BJ, Sen A, Jha S, Rai A, Paudel V, Sah R. 2018. Impact on birth weight and child growth of Participatory Learning and Action women's groups with and without transfers of food or cash during pregnancy: Findings of the low birth weight South Asia cluster-randomised controlled trial (LBWSAT) in Nepal. PLOS ONE 13:e0194064. DOI: https://doi.org/10.1371/journal.pone.0194064.

Saville NM, Shrestha BP, Style S, Harris-Fry H, Beard BJ, Sengupta A, Jha S, Rai A, Paudel V, Pulkki-Brannstrom A-M. 2016. Protocol of the Low Birth Weight South Asia Trial (LBWSAT), a cluster-randomised controlled trial testing impact on birth weight and infant nutrition of participatory learning and action through women's groups, with and without unconditional transfers of fortified food or cash during pregnancy in Nepal. BMC Pregnancy and Childbirth 16:320. DOI: https://doi.org/10.1186/s12884-016-1102-x.

Schaffnit SB, Urassa M, Lawson DW. 2019. "Child marriage” in context: exploring local attitudes towards early marriage in rural Tanzania. Sexual and Reproductive Health Matters 27:1571304. DOI: 10.1080/09688080.2019.1571304.

Scott S, Nguyen PH, Neupane S, Pramanik P, Nanda P, Bhutta ZA, Afsana K, Menon P. 2021. Early marriage and early childbearing in South Asia: trends, inequalities, and drivers from 2005 to 2018. Annals of the New York Academy of Sciences 1491:60-73. DOI: https://doi.org/10.1111/nyas.14531.

Sekine K, Hodgkin ME. 2017. Effect of child marriage on girls' school dropout in Nepal: Analysis of data from the Multiple Indicator Cluster Survey 2014. PLOS ONE 12:e0180176. DOI: 10.1371/journal.pone.0180176.

Singh A, Espinoza Revollo P. 2016. Teenage marriage, fertility, and well-being: Panel evidence from India. London: UK: Young Lives https://www.younglives.org.uk/content/teenagemarriage-fertility-and-well-being-panel-evidence-india (accessed 15 September 2021).

Stash S, Hannum E. 2001. Who goes to school? Educational stratification by gender, caste, and ethnicity in Nepal. Comparative Education Review 45:354-378. DOI: https://doiorg.ezp.lib.cam.ac.uk/10.1086/447676.

UN General Assembly. 2014. Resolution on Early, Child and Forced Marriage. New York: USA: UN General Assembly. Available at

Peer] reviewing PDF | (2021:07:63393:1:0:NEW 21 Sep 2021) 
961 https://www.who.int/pmnch/media/events/2014/child_marriage/en/ (accessed 12 April 962 2021).

963 UN General Assembly. 2018. Resolution on Early, Child and Forced Marriage. New York:

964 USA: UN General Assembly https://undocs.org/A/C.3/73/L.22/Rev.1 (Accessed 12 April 965 2021).

966 UNFPA. 2012. Marrying too young: End child marriage. New York: USA: UNFPA. Available

967 at https:/www.unfpa.org/sites/default/files/pub-pdf/MarryingTooYoung.pdf (accessed 12

968

969

970

971

972

973

974

975

976

977

978

979

980

981

982

983

984

985

986

987

988

989

990

991

992

993

994

995

996

997 April 2021).

UNICEF. 2014. Ending Child Marriage: Progress and prospects. New York: USA: UNCEF. Available at https://data.unicef.org/resources/ending-child-marriage-progress-andprospects/ (accessed 12 April 2021).

UNICEF. 2021.Global database on child marriage. Available at https://data.unicef.org/topic/child-protection/child-marriage/ (accessed June 8, 2021).

UNICEF, UNFPA. 2017. Ending child marriage in Nepal. Kathmandu: Nepal: UNICEF South Asia and UNFPA Asia and the Pacific Regional Office. Available at https://www.unicef.org/nepal/media/401/file/Ending\%20Child\%20Marriage\%20in\%20N epal.pdf (accessed 19 May 2021).

Verma R, Sinha T, Khanna T. 2013. Asia child marriage initiative: Summary of research in Bangladesh, India and Nepal. Bangkok: Thailand: Plan Asia Regional Office and ICRW. https://www.icrw.org/wp-content/uploads/2016/10/PLAN-ASIA-Child-Marriage-3Country-Study.pdf (accessed 19 May 2021).

Wells JCK, Marphatia AA, Cortina-Borja M, Manandhar DS, Reid AM, Saville N. 2021. Maternal physical, socioeconomic, and demographic characteristics and childbirth complications in rural lowland Nepal: Applying an evolutionary framework to understand the role of phenotypic plasticity. American Journal of Human Biology e23566. DOI: https://doi-org.ezp.lib.cam.ac.uk/10.1002/ajhb.23566.

Wickham H. 2016. Ggplot2: Elegant graphics for data analysis. New York: USA: SpringerVerlag.

Wickham H, Averick M, Bryan J, Chang W, McGowan LD, François R, Grolemund G, Hayes A, Henry L, Hester J. 2019. Welcome to the Tidyverse. Journal of Open Source Software 4:1686. DOI: $10.21105 /$ joss.01686.

Wodon QT, Male C, Nayihouba KA, Onagoruwa AO, Savadogo A, Yedan A, Edmeades J, Kes A, John N, Murithi L, Steinhaus M, Petroni S. 2017. Economic impacts of child marriage : global synthesis report. World Bank https://documents1.worldbank.org/curated/en/530891498511398503/pdf/116829-WPP151842-PUBLIC-EICM-Global-Conference-Edition-June-27.pdf (accessed 12 April 2021).

998 
Figure 1

Early marriage groups used in analysis

Our first outcome variable, women's 'early marriage,' uses four different age groupings, described as Scenarios A, B, C and D in the Figure. To ensure comparability across these results, the same reference group, marrying at the minimum age cut-off of $\geq 18$ years, is used irrespective of the age used to define early marriage. Each of the scenarios above the $<15$ years has the lower group nested within it, but excludes the higher group up to 18 years.

\section{Scenario A: we predict being married $<15 y$, compared to those $\geq 18 y$}

Scenario B: we predict being married $<16 y$, compared to those $\geq 18 \mathrm{y}$

Scenario C: we predict being married $<17 y$, compared to those $\geq 18 y$

Scenario D: we predict being married $<18 y$, compared to those $\geq 18 y$

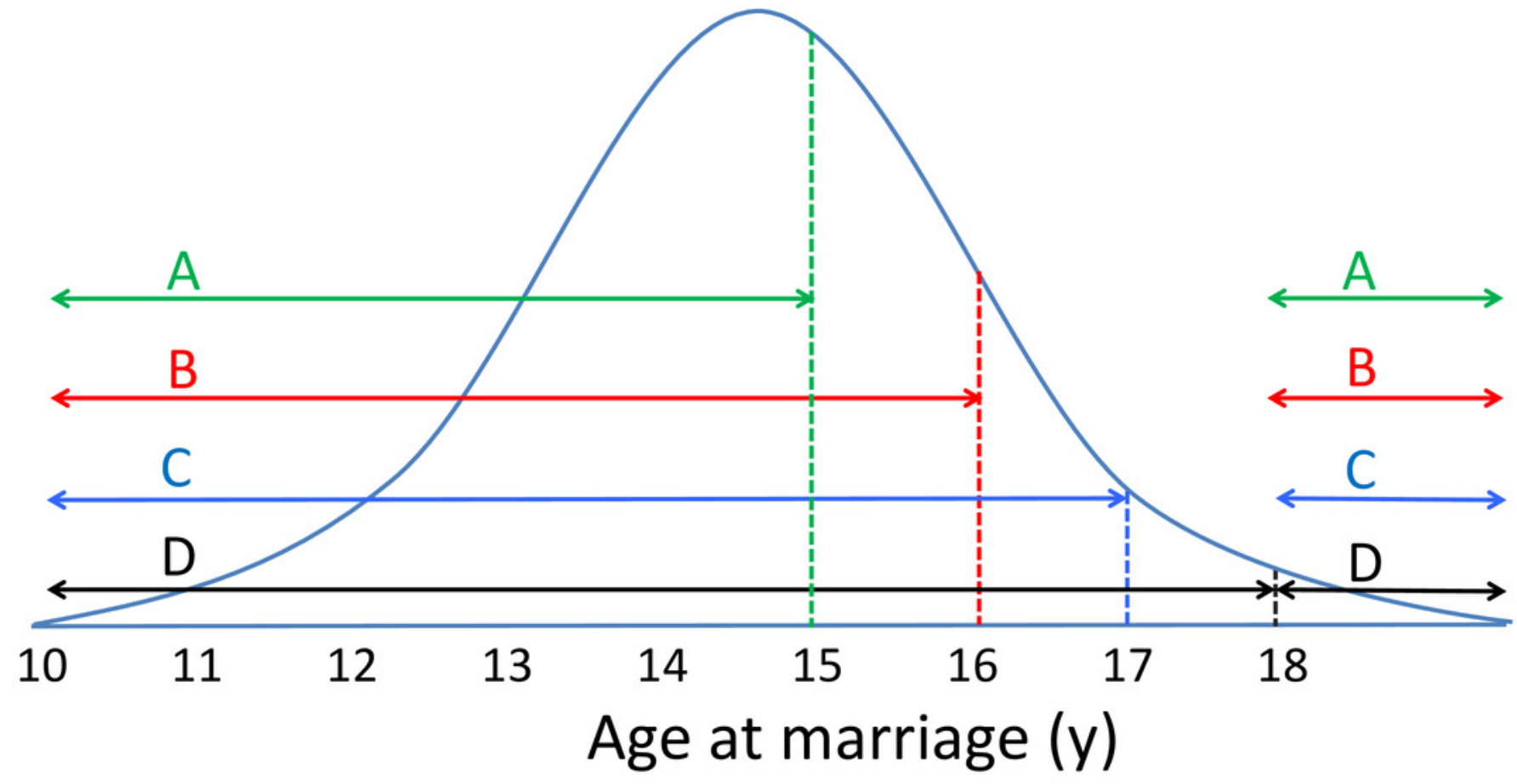


Figure 2

Association of women's marriage age and their education level stratified by natal household asset score

This figure uses the raw data to stratify the association of women's marriage age with women's education by natal household asset quintiles. 

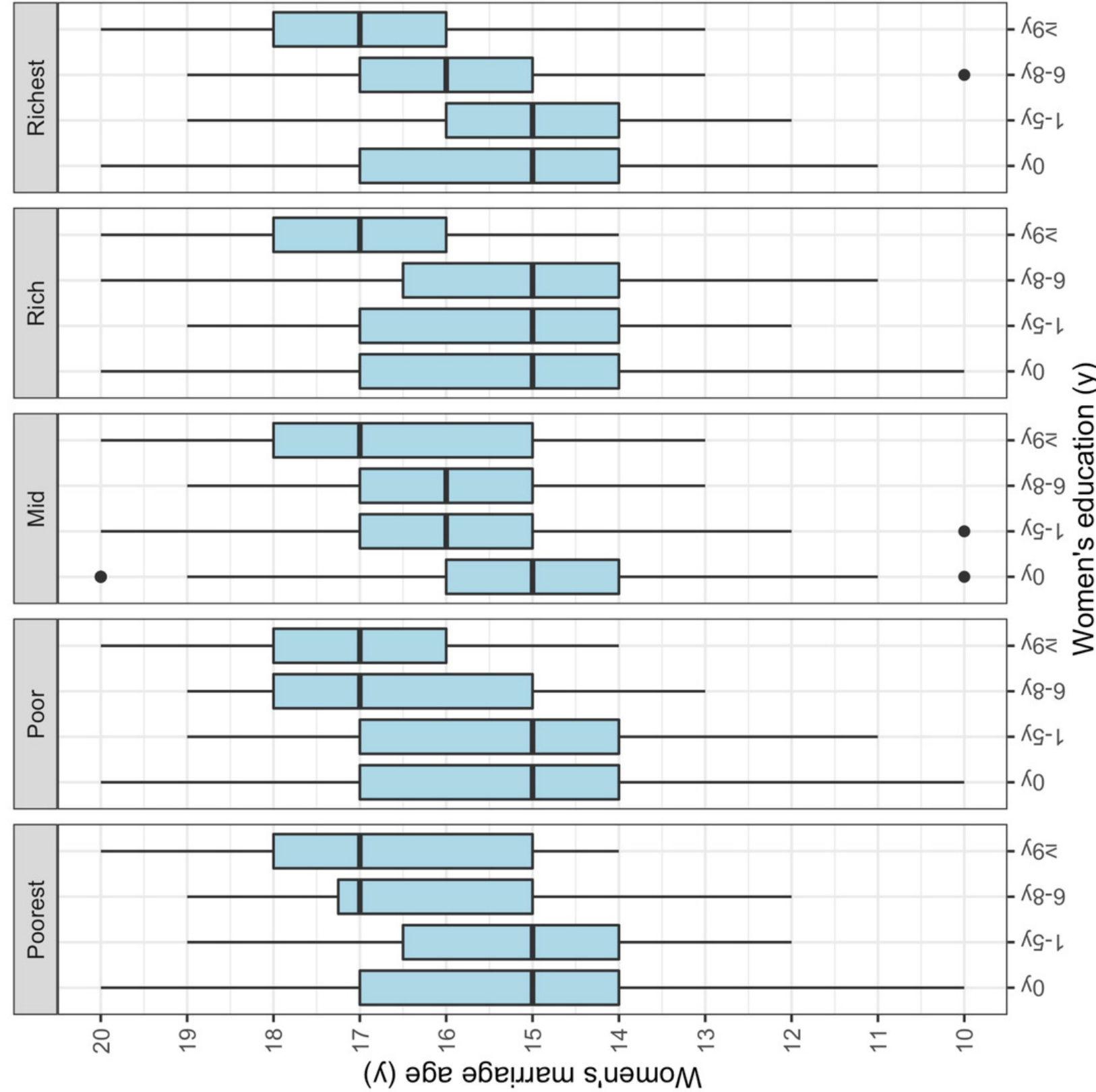
Table $\mathbf{1}$ (on next page)

Description of sample 


\begin{tabular}{|c|c|c|}
\hline & \multicolumn{2}{|c|}{$\begin{array}{l}\text { Traits measured in women's natal household } \\
\qquad(n=2,432)\end{array}$} \\
\hline & Median & IQR \\
\hline Women's age (y) & 21 & 4 \\
\hline Women's age at marriage $(\mathrm{y})$ & 15 & 3 \\
\hline \multirow{2}{*}{ Time since marriage $(\mathrm{y})$} & 5 & 5 \\
\hline & Frequency & $\%$ \\
\hline \multicolumn{3}{|l|}{ Trial intervention arm } \\
\hline Control & 429 & 17.6 \\
\hline Women's Group & 446 & 18.3 \\
\hline Women's Group with cash transfer & 793 & 32.6 \\
\hline Women's Group with food supplement & 764 & 31.4 \\
\hline \multicolumn{3}{|l|}{ Women's age at marriage (y) } \\
\hline$<15$ years & 666 & 27.4 \\
\hline 15 years & 574 & 23.6 \\
\hline 16 years & 356 & 14.6 \\
\hline 17 years & 408 & 16.8 \\
\hline$\geq 18$ years & 428 & 17.6 \\
\hline \multicolumn{3}{|l|}{ Women's education level (y) } \\
\hline None & 1,610 & 66.2 \\
\hline Primary (1-5 years) & 244 & 10.0 \\
\hline Lower-secondary (6-8 years) & 196 & 8.1 \\
\hline Secondary or higher ( $\geq 9$ years) & 382 & 15.7 \\
\hline \multicolumn{3}{|l|}{ Natal household asset score (quintiles) } \\
\hline 1: poorest & 525 & 21.6 \\
\hline 2: 2nd poorest & 484 & 19.9 \\
\hline 3: middle & 528 & 21.7 \\
\hline 4: 2 nd richest & 465 & 19.1 \\
\hline 5: richest & 430 & 17.7 \\
\hline \multicolumn{3}{|l|}{ Natal household agrarian land-holding } \\
\hline None & 951 & 39.1 \\
\hline 0.01 to 0.5 hectares & 750 & 30.8 \\
\hline 0.51 to 0.99 hectares & 344 & 14.1 \\
\hline$\geq 1$ hectare & 387 & 15.9 \\
\hline \multicolumn{3}{|l|}{ Natal household access to big bazaar } \\
\hline$<30$ minutes & 798 & 32.8 \\
\hline $30-59$ minutes & 934 & 38.4 \\
\hline $60-89$ minutes & 472 & 19.4 \\
\hline$\geq 90$ minutes & 228 & 9.4 \\
\hline \multicolumn{3}{|l|}{ Natal household caste affiliation } \\
\hline Disadvantaged: Dalit & 494 & 20.3 \\
\hline Disadvantaged: Muslim & 468 & 19.2 \\
\hline Middle: Janjati, Terai castes & 927 & 38.1 \\
\hline Advantaged: Yadav, Brahmin & 543 & 22.3 \\
\hline
\end{tabular}

\section{Table 1. Description of sample}

$2 \mathrm{IQR}$, interquartile range. 


\section{Table 2 (on next page)}

Heat map of women's educational attainment by natal household wealth

The heat table shows the overall number of women by their education level and natal household wealth quintiles. Green shaded areas indicate low numbers and red shaded numbers the highest numbers. 
1 Table 2. Heat map of women's educational attainment by natal household wealth

2

\begin{tabular}{|l|c|c|c|c|c|c|}
\hline & \multicolumn{5}{|c|}{ Natal household asset quintiles } \\
\hline Women's education (y) & Poorest & 2nd Poorest & Mid-level & 2nd Richest & Richest & Total row \\
\hline None & 464 & 351 & 356 & 255 & 184 & 1,610 \\
\hline Primary (1-5 years) & 27 & 50 & 61 & 56 & 50 & 244 \\
\hline Lower-secondary (6-8 years) & 20 & 38 & 41 & 59 & 38 & 196 \\
\hline Secondary/higher ( $\geq 9$ years) & 14 & 45 & 70 & 95 & 158 & 382 \\
\hline Total column & 525 & 484 & 528 & 465 & 430 & 2,432 \\
\hline
\end{tabular}

3

4 


\section{Table 3 (on next page)}

Hypothesis 1: Associations of natal household asset score with marrying early 
1 Table 3. Hypothesis 1: Associations of natal household asset score with women's early marriage

\begin{tabular}{|c|c|c|c|c|c|c|c|c|}
\hline & \multicolumn{2}{|c|}{$\begin{array}{c}\text { Model 1: } \text { Marrying }<\mathbf{1 5} \\
\text { years } \\
n=1,094^{1} R^{2}=0.050\end{array}$} & \multicolumn{2}{|c|}{$\begin{array}{c}\text { Model 2: } \text { Marrying }<\mathbf{1 6} \\
\text { years } \\
n=1,668^{2} R^{2}=0.032\end{array}$} & \multicolumn{2}{|c|}{$\begin{array}{c}\text { Model 3: } \text { Marrying }<17 \\
\text { years } \\
n=2,024^{3} R^{2}=0.028 \\
\end{array}$} & \multicolumn{2}{|c|}{$\begin{array}{c}\text { Model 4: } \text { Marrying }<18 \\
\text { years } \\
n=2,432^{4} R^{2}=0.021\end{array}$} \\
\hline & aOR (95\% CI) & $p$-value & aOR (95\% CI) & $p$-value & aOR (95\% CI) & $p$-value & aOR (95\% CI) & $\begin{array}{c}p- \\
\text { value }\end{array}$ \\
\hline Women's age (y) & $1.02(0.97,1.06)$ & & $1.01(0.97,1.0$ & & $0.99(0.96,1)$. & & & 0.178 \\
\hline Asse & & & & & & & & \\
\hline Poorest & $2.98(1.90,4.67)$ & $<0.001$ & $2.44(1.67,3.58)$ & $<0.001$ & $2.26(1.58,3.24)$ & $<0.011$ & $1.93(1.372 .72)$ & $<0.001$ \\
\hline $2^{\text {nd }}$ poorest & $2.39(1.53,3.71)$ & $<0.001$ & $1.68(1.16,2.44)$ & 0.007 & $1.57(1.11,2.23)$ & 0.002 & $1.41(1.01,1.97)$ & 0.043 \\
\hline Mid & $2.12(1.35,3.31)$ & 0.001 & $1.83(1.26,2.66)$ & 0.001 & $1.74(1.23,2.47)$ & 0.001 & $1.52(1.09,2.12)$ & 0.013 \\
\hline $2^{\text {nd }}$ richest & $2.34(1.49,3.69)$ & $<0.001$ & $1.93(1.31,2.83)$ & 0.001 & $1.90(1.32,2.73)$ & $<0.001$ & $1.72(1.22,2.43)$ & 0.002 \\
\hline Richest (ref) & 1.00 & & 1.00 & & 1.00 & & 1.00 & \\
\hline Intercept & $0.52(0.16,1.72)$ & 0.286 & $1.46(0.53,3.97)$ & 0.462 & $3.11(1.23,7.86)$ & 0.017 & $6.00(2.54,14.15)$ & $<0.001$ \\
\hline
\end{tabular}

2 Models include fixed and random effects estimates for geographic clusters and control for trial arm. As associations of trial arm with early marriage across the

3 age groupings were not statistically significant, they are not reported in Tables. aOR, adjusted Odds Ratio. CI, $95 \%$ Confidence Interval. ${ }^{1} n=428$ married $\geq 18 \mathrm{y}$ vs $4 n=666$ married $<15 \mathrm{y} .{ }^{2} n=428$ married $\geq 18 \mathrm{y}$ vs $n=1,240$ married $<16 \mathrm{y} .{ }^{3} n=428$ married $\geq 18 \mathrm{y}$ vs $n=1,596$ married $<17 \mathrm{y} .{ }^{4} n=428$ married $\geq 18 \mathrm{y}$ vs $n=2,004$ married $5<18 \mathrm{y}$. 


\section{Table 4 (on next page)}

Hypothesis 2: Broader socio-economic factors associated with women marrying early 
1 Table 4. Hypothesis 2: Broader socio-economic factors associated with women's early marriage

\begin{tabular}{|c|c|c|c|c|c|c|c|c|}
\hline & \multicolumn{2}{|c|}{$\begin{array}{c}\text { Model 1: } \text { Marrying }<\mathbf{1 5} \\
\text { years } \\
n=1,094^{1} R^{2}=0.235\end{array}$} & \multicolumn{2}{|c|}{$\begin{array}{c}\text { Model 2: } \text { Marrying }<\mathbf{1 6} \\
\text { years } \\
n=1,668^{2} R^{2}=0.164 \\
\end{array}$} & \multicolumn{2}{|c|}{$\begin{array}{c}\text { Model 3: } \text { Marrying }<17 \\
\text { years } \\
n=2,024^{3} R^{2}=0.131 \\
\end{array}$} & \multicolumn{2}{|c|}{$\begin{array}{c}\text { Model 4: } \text { Marrying }<\mathbf{1 8} \\
\text { years } \\
n=2,432^{4} R^{2}=0.106 \\
\end{array}$} \\
\hline & aOR (95\% CI) & $\begin{array}{c}p- \\
\text { value }\end{array}$ & aOR (95\% CI) & $\begin{array}{c}p- \\
\text { value }\end{array}$ & aOR (95\% CI) & $p$-value & aOR (95\% CI) & $p$-value \\
\hline Women's age $(y)$ & $0.99(0.94,1.04)$ & 0.670 & $0.98(0.94,1.02)$ & 0.401 & $0.96(0.93,1.00)$ & 0.047 & $0.95(0.91,0.98)$ & 0.003 \\
\hline \multicolumn{9}{|l|}{ Asset score } \\
\hline Poorest & $1.04(0.58,1.85)$ & 0.902 & $0.90(0.55,1.44)$ & 0.651 & $0.98(0.63,1.53)$ & 0.933 & $0.92(0.60,1.39)$ & 0.675 \\
\hline $2^{\text {nd }}$ poorest & $1.02(0.59,1.74)$ & 0.949 & $0.74(0.47,1.15)$ & 0.184 & $0.82(0.55,1.23)$ & 0.338 & $0.79(0.54,1.16)$ & 0.233 \\
\hline Mid & $0.95(0.56,1.63)$ & 0.863 & $0.91(0.59,1.40)$ & 0.658 & $1.01(0.68,1.50)$ & 0.948 & $0.94(0.65,1.37)$ & 0.763 \\
\hline $2^{\text {nd }}$ richest & $1.61(0.94,2.75)$ & 0.083 & $1.30(0.84,2.02)$ & 0.233 & $1.48(1.00,2.21)$ & 0.051 & $1.31(0.90,1.89)$ & 0.157 \\
\hline Richest (ref) & 1.00 & & 1.00 & & 1.00 & & 1.00 & \\
\hline \multicolumn{9}{|l|}{ Women's education } \\
\hline None & $\begin{array}{c}18.43(10.60, \\
32.03)\end{array}$ & $<0.001$ & $\begin{array}{c}11.50(7.66 \\
17.28)\end{array}$ & $<0.001$ & $8.00(5.59,11.47)$ & $<0.001$ & $5.65(4.07,7.84)$ & $<0.001$ \\
\hline Primary $(1-5 y)$ & $\begin{array}{c}11.72(6.06 \\
22.68)\end{array}$ & $<0.001$ & $7.21(4.30,12.08)$ & $<0.001$ & $5.07(3.18,8.08)$ & $<0.001$ & $3.81(2.46,5.89)$ & $<0.001$ \\
\hline Lower-secondary (6-8y) & $5.23(2.56,10.66)$ & $<0.001$ & $4.56(2.64,7.88)$ & $<0.001$ & $3.96(2.43,6.45)$ & $<0.001$ & $3.43(2.18,5.41)$ & $<0.001$ \\
\hline Secondary/higher $(\geq 9)$ (ref) & 1.00 & & 1.00 & & 1.00 & & 1.00 & \\
\hline \multicolumn{9}{|l|}{ Agrarian land } \\
\hline None & $1.05(0.61,1.79)$ & 0.866 & $1.06(0.68,1.65)$ & 0.793 & $0.95(0.63,1.43)$ & 0.819 & $0.98(0.67,1.44)$ & 0.927 \\
\hline 0.01 to 0.5 hectares & $1.36(0.81,2.26)$ & 0.242 & $1.42(0.93,2.15)$ & 0.104 & $1.26(0.85,1.85)$ & 0.246 & $1.32(0.92,1.89)$ & 0.136 \\
\hline 0.51 to 0.99 hectares & $0.96(0.55,1.69)$ & 0.895 & $1.08(0.68,1.70)$ & 0.746 & $1.09(0.72,1.65)$ & 0.688 & $1.09(0.74,1.60)$ & 0.671 \\
\hline$\geq 1$ hectare (ref) & 1.00 & & 1.00 & & 1.00 & & 1.00 & \\
\hline \multicolumn{9}{|l|}{ Access to big bazaar } \\
\hline$<30 \min (\mathrm{ref})$ & 1.00 & & 1.00 & & 1.00 & & 1.00 & \\
\hline $30-59$ minutes & $1.09(0.71,1.68)$ & 0.682 & $1.15(0.80,1.64)$ & 0.443 & $1.03(0.74,1.44)$ & 0.841 & $1.09(0.80,1.48)$ & 0.605 \\
\hline $60-89$ minutes & $1.11(0.66,1.87)$ & 0.702 & $1.17(0.76,1.80)$ & 0.471 & $1.01(0.68,1.51)$ & 0.954 & $1.01(0.70,1.46)$ & 0.967 \\
\hline$\geq 90$ minutes & $1.32(0.69,2.53)$ & 0.409 & $1.14(0.65,2.01)$ & 0.650 & $0.90(0.53,1.52)$ & 0.687 & $1.03(0.63,1.68)$ & 0.912 \\
\hline \multicolumn{9}{|l|}{ Caste } \\
\hline Disadvantaged: Dalit & $0.98(0.56,1.71)$ & 0.931 & $1.13(0.71,1.78)$ & 0.616 & $1.19(0.78,1.83)$ & 0.425 & $1.20(0.80,1.79)$ & 0.376 \\
\hline Disadvantaged: Muslim & $1.01(0.59,1.71)$ & 0.984 & $0.99(0.63,1.55)$ & 0.956 & $1.01(0.67,1.55)$ & 0.946 & $1.03(0.69,1.54)$ & 0.883 \\
\hline Middle: Janjati, Terai castes & $0.99(0.63,1.54)$ & 0.953 & $1.13(0.78,1.62)$ & 0.517 & $1.13(0.81,1.58)$ & 0.467 & $1.09(0.80,1.49)$ & 0.576 \\
\hline $\begin{array}{l}\text { Advantaged: Yadav, Brahmin } \\
\text { (ref) }\end{array}$ & 1.00 & & 1.00 & & 1.00 & & 1.00 & \\
\hline Intercept & $0.14(0.03,0.59)$ & 0.007 & $0.55(0.17,1.77)$ & 0.316 & $1.63(0.57,4.72)$ & 0.363 & $\begin{array}{c}4.01(1.53 \\
10.52)\end{array}$ & 0.005 \\
\hline
\end{tabular}


2 Models include fixed and random effects estimates for geographic clusters and control for trial arm. aOR, adjusted Odds Ratio. CI, $95 \%$ Confidence Interval. $3{ }^{1} n=428$ married $\geq 18 \mathrm{y}$ vs $n=666$ married $<15 \mathrm{y} .{ }^{2} n=428$ married $\geq 18 \mathrm{y}$ vs $n=1,240$ married $<16 \mathrm{y} .{ }^{3} n=428$ married $\geq 18 \mathrm{y}$ vs $n=1,596$ married $<17 \mathrm{y} .{ }^{4} n=428$ married $4 \geq 18 \mathrm{y}$ vs $n=2,004$ married $<18 \mathrm{y}$. 


\section{Table 5 (on next page)}

Hypothesis 3: Associations of natal household asset score and marrying early in uneducated women 
1 Table 5. Hypothesis 3: Associations of natal household asset score and early marriage in uneducated women

\begin{tabular}{|c|c|c|c|c|c|c|c|c|}
\hline & \multicolumn{2}{|c|}{$\begin{array}{c}\text { Model 1: } \text { Marrying <15 } \\
\text { years } \\
n=736^{1} R^{2}=0.062 \\
\end{array}$} & \multicolumn{2}{|c|}{$\begin{array}{c}\text { Model 2: } \text { Marrying }<\mathbf{1 6} \\
\text { years } \\
n=1,156^{2} R^{2}=0.054 \\
\end{array}$} & \multicolumn{2}{|c|}{$\begin{array}{c}\text { Model 3: Marrying }<17 \\
\text { years } \\
n=1,376^{3} R^{2}=0.050\end{array}$} & \multicolumn{2}{|c|}{$\begin{array}{c}\text { Model 4: Marrying }<\mathbf{1 8} \\
\text { years } \\
n=1,610^{4} R^{2}=0.050\end{array}$} \\
\hline & aOR $(95 \% \mathrm{CI})$ & $p$-value & aOR $(95 \%$ CI $)$ & $p$-value & aOR $(95 \% \mathrm{CI})$ & $p$-value & aOR $(95 \%$ CI $)$ & $p$-value \\
\hline Women's age (y) & $1.00(0.94,1.06)$ & 0.951 & $1.00(0.95,1.05)$ & 0.923 & $0.98(0.94,1.03)$ & 0.474 & $0.98(0.93,1.02)$ & 0.316 \\
\hline \multicolumn{9}{|l|}{ Asset score } \\
\hline Poorest & $0.89(0.46,1.72)$ & 0.733 & $0.87(0.48,1.57)$ & 0.634 & $0.91(0.52,1.61)$ & 0.756 & $0.82(0.48,1.41)$ & 0.470 \\
\hline $2^{\text {nd }}$ poorest & $0.83(0.43,1.62)$ & 0.590 & $0.69(0.37,1.27)$ & 0.231 & $0.70(0.39,1.25)$ & 0.228 & $0.67(0.38,1.16)$ & 0.155 \\
\hline Mid & $0.87(0.44,1.71)$ & 0.679 & $0.83(0.45,1.54)$ & 0.560 & $0.83(0.46,1.50)$ & 0.544 & $0.75(0.43,1.32)$ & 0.319 \\
\hline $2^{\text {nd }}$ richest & $1.71(0.80,3.65)$ & 0.168 & $1.53(0.76,3.11)$ & 0.235 & $1.48(0.75,2.93)$ & 0.258 & $1.48(0.77,2.84)$ & 0.241 \\
\hline Richest (ref) & 1.00 & & 1.00 & & 1.00 & & 1.00 & \\
\hline Intercept & $\begin{array}{c}3.28(0.70 \\
15.41)\end{array}$ & 0.133 & $\begin{array}{c}7.14(1.74 \\
29.26)\end{array}$ & 0.006 & $\begin{array}{c}12.28(3.27 \\
46.17)\end{array}$ & $<0.001$ & $\begin{array}{c}17.30(4.98 \\
60.07)\end{array}$ & $<0.001$ \\
\hline
\end{tabular}

2 Models include fixed and random effects estimates for geographic clusters and control for trial arm. aOR, adjusted Odds Ratio. CI, 95\% Confidence Interval.

$3{ }^{1} n=206$ married $\geq 18 \mathrm{y}$ vs $n=530$ married $<15 \mathrm{y} .{ }^{2} n=206$ married $\geq 18 \mathrm{y}$ vs $n=950$ married $<16 \mathrm{y} .{ }^{3} n=206$ married $\geq 18 \mathrm{y}$ vs $n=1,170$ married $<17 \mathrm{y} .{ }^{4} n=206$ married $4 \geq 18 \mathrm{y}$ vs $n=1,404$ married $<18 \mathrm{y}$. 
Table 6(on next page)

Hypothesis 3: Broader socio-economic factors associated with women marrying early in uneducated women 
1 Table 6. Hypothesis 3: Broader socio-economic factors associated with early marriage in uneducated women

\begin{tabular}{|c|c|c|c|c|c|c|c|c|}
\hline & \multicolumn{2}{|c|}{$\begin{array}{c}\text { Model 1: } \text { Marrying }<\mathbf{1 5} \\
\text { years } \\
n=736^{1} R^{2}=0.071\end{array}$} & \multicolumn{2}{|c|}{$\begin{array}{c}\text { Model 2: } \text { Marrying <16 } \\
\text { years } \\
n=1,156^{2} R^{2}=0.066 \\
\end{array}$} & \multicolumn{2}{|c|}{$\begin{array}{c}\text { Model 3: } \text { Marrying }<\mathbf{1 7} \\
\text { years } \\
n=1,376^{3} R^{2}=0.058\end{array}$} & \multicolumn{2}{|c|}{$\begin{array}{c}\text { Model 4: } \text { Marrying }<\mathbf{1 8} \\
\text { years } \\
n=1,610^{4} R^{2}=0.060 \\
\end{array}$} \\
\hline & aOR (95\% CI) & $\begin{array}{c}p- \\
\text { value }\end{array}$ & aOR (95\% CI) & $p$-value & aOR (95\% CI) & $p$-value & aOR (95\% CI) & $p$-value \\
\hline Women's age (y) & $1.00(0.95,1.06)$ & 0.959 & $1.00(0.95,1.05)$ & 0.995 & $0.98(0.94,1.03)$ & 0.482 & $0.98(0.93,1.02)$ & 0.338 \\
\hline \multicolumn{9}{|l|}{ Asset score } \\
\hline Poorest & $0.75(0.36,1.57)$ & 0.449 & $0.78(0.40,1.49)$ & 0.446 & $0.86(0.46,1.61)$ & 0.639 & $0.78(0.43,1.40)$ & 0.400 \\
\hline $2^{\text {nd }}$ poorest & $0.74(0.37,1.50)$ & 0.402 & $0.63(0.33,1.20)$ & 0.163 & $0.65(0.35,1.20)$ & 0.172 & $0.62(0.35,1.12)$ & 0.115 \\
\hline Mid & $0.79(0.39,1.59)$ & 0.503 & $0.77(0.41,1.46)$ & 0.432 & $0.79(0.43,1.45)$ & 0.439 & $0.72(0.40,1.28)$ & 0.260 \\
\hline $2^{\text {nd }}$ richest & $1.56(0.72,3.38)$ & 0.262 & $1.45(0.71,2.96)$ & 0.311 & $1.41(0.71,2.82)$ & 0.325 & $1.43(0.74,2.77)$ & 0.287 \\
\hline Richest (ref) & 1.00 & & 1.00 & & 1.00 & & 1.00 & \\
\hline \multicolumn{9}{|l|}{ Agrarian land } \\
\hline None & $1.41(0.72,2.78)$ & 0.315 & $1.24(0.69,2.25)$ & 0.476 & $1.16(0.65,2.06)$ & 0.609 & $1.26(0.73,2.18)$ & 0.402 \\
\hline 0.01 to $0.5 \mathrm{hec}$ & $1.59(0.81,3.11)$ & 0.179 & $1.48(0.82,2.68)$ & 0.196 & $1.46(0.82,2.59)$ & 0.200 & $1.67(0.97,2.89)$ & 0.066 \\
\hline 0.51 to 0.99 hectares & $1.21(0.55,2.67)$ & 0.634 & $1.18(0.58,2.39)$ & 0.646 & $1.18(0.60,2.31)$ & 0.638 & $1.32(0.69,2.53)$ & 0.395 \\
\hline$\geq 1$ hectare (ref) & 1.00 & & 1.00 & & 1.00 & & 1.00 & \\
\hline \multicolumn{9}{|l|}{ Access to big bazaar } \\
\hline$<30 \min (\mathrm{ref})$ & 1.00 & & 1.00 & & 1.00 & & 1.00 & \\
\hline $30-59$ minutes & $0.94(0.56,1.57)$ & 0.810 & $0.91(0.57,1.44)$ & 0.687 & $0.89(0.57,1.38)$ & 0.597 & $0.92(0.61,1.41)$ & 0.715 \\
\hline $60-89$ minutes & $1.10(0.58,2.09)$ & 0.777 & $1.35(0.76,2.43)$ & 0.308 & $1.19(0.68,2.07)$ & 0.536 & $1.18(0.70,2.00)$ & 0.536 \\
\hline$\geq 90$ minutes & $1.47(0.67,3.22)$ & 0.331 & $1.29(0.61,2.70)$ & 0.506 & $1.09(0.54,2.20)$ & 0.803 & $1.10(0.56,2.14)$ & 0.790 \\
\hline \multicolumn{9}{|l|}{ Caste } \\
\hline Disadvantaged: Dalit & $1.09(0.54,2.20)$ & 0.800 & $1.03(0.56,1.89)$ & 0.933 & $1.01(0.56,1.82)$ & 0.973 & $1.07(0.61,1.88)$ & 0.813 \\
\hline Disadvantaged: Muslim & $0.96(0.50,1.82)$ & 0.890 & $0.85(0.48,1.51)$ & 0.576 & $0.87(0.50,1.50)$ & 0.610 & $0.88(0.52,1.49)$ & 0.642 \\
\hline Middle: Janjati, Terai castes & $0.96(0.53,1.74)$ & 0.904 & $1.00(0.59,1.69)$ & 0.996 & $1.00(0.60,1.66)$ & 0.996 & $0.96(0.59,1.56)$ & 0.865 \\
\hline $\begin{array}{l}\text { Advantaged: Yadav, Brahmin } \\
\text { (ref) }\end{array}$ & 1.00 & & 1.00 & & 1.00 & & 1.00 & \\
\hline Intercept & $\begin{array}{c}2.27(0.40, \\
12.91)\end{array}$ & 0.354 & $5.62(1.16,27.28)$ & 0.032 & $\begin{array}{c}10.94(2.48 \\
48.26)\end{array}$ & 0.002 & $\begin{array}{l}13.49(3.31 \\
55.02)\end{array}$ & $<0.001$ \\
\hline
\end{tabular}

2 Models include fixed and random effects estimates for geographic clusters and control for trial arm. aOR, Adjusted Odds Ratio. CI, 95\% Confidence Interval

$3{ }^{1} n=206$ married $\geq 18 \mathrm{y}$ vs $n=530$ married $<15 \mathrm{y} .{ }^{2} n=206$ married $\geq 18 \mathrm{y}$ vs $n=950$ married $<16 \mathrm{y} .{ }^{3} n=206$ married $\geq 18 \mathrm{y}$ vs $n=1,170$ married $<17 \mathrm{y} .{ }^{4} n=206$ married

$4 \geq 18 \mathrm{y}$ vs $n=1,404$ married $<18 \mathrm{y}$. 


\section{Table 7 (on next page)}

Hypothesis 4: Broader socio-economic factors associated with women being uneducated 
1 Table 7. Hypothesis 4: Broader socio-economic factors associated with women being

2 uneducated

\begin{tabular}{|c|c|c|c|c|}
\hline & \multicolumn{2}{|c|}{$\begin{array}{c}\text { Model 1: Natal household } \\
\text { asset score } \\
n=2,432^{1} R^{2}=0.210\end{array}$} & \multicolumn{2}{|c|}{$\begin{array}{c}\text { Model 2: Broader socio- } \\
\text { economic factors } \\
n=2,432^{1} \quad R^{2}=0.363\end{array}$} \\
\hline & OR (95\% CI) & $p$-value & aOR (95\% CI) & $p$-value \\
\hline Women's age $(y)$ & $1.16(1.12,1.20)$ & $<0.001$ & $1.18(1.14,1.23)$ & $<0.001$ \\
\hline Asset score & 1.00 & & 1.00 & \\
\hline Poorest & $11.84(8.36,16.77)$ & $<0.001$ & $8.79(5.97,12.95)$ & $<0.001$ \\
\hline $2^{\text {nd }}$ poorest & $4.01(2.97,5.40)$ & $<0.001$ & $3.60(2.59,5.01)$ & $<0.001$ \\
\hline Mid & $3.18(2.39,4.23)$ & $<0.001$ & $3.16(2.31,4.34)$ & $<0.001$ \\
\hline $2^{\text {nd }}$ richest & $1.68(1.27,2.22)$ & $<0.001$ & $1.68(1.23,2.28)$ & $<0.001$ \\
\hline Richest (ref) & & & 1.00 & \\
\hline \multicolumn{5}{|l|}{ Agrarian land } \\
\hline None & & & $2.99(2.15,4.18)$ & $<0.001$ \\
\hline 0.01 to 0.5 hectares & & & $1.79(1.33,2.42)$ & $<0.001$ \\
\hline 0.51 to 0.99 hectares & & & $1.17(0.84,1.63)$ & 0.351 \\
\hline$\geq 1$ hectare (ref) & & & 1.00 & \\
\hline \multicolumn{5}{|l|}{ Access to big bazaar } \\
\hline$<30 \min ($ ref $)$ & & & 1.00 & \\
\hline $30-59$ minutes & & & $1.18(0.90,1.55)$ & 0.220 \\
\hline $60-89$ minutes & & & $1.16(0.83,1.60)$ & 0.387 \\
\hline$\geq 90$ minutes & & & $1.62(1.05,2.51)$ & 0.031 \\
\hline \multicolumn{5}{|l|}{ Caste } \\
\hline Disadvantaged: Dalit & & & $1.66(1.18,2.35)$ & 0.004 \\
\hline Disadvantaged: Muslim & & & $7.12(4.83,10.49)$ & $<0.001$ \\
\hline Middle: Janjati, Terai castes & & & $0.99(0.76,1.29)$ & 0.927 \\
\hline Advantaged: Yadav, Brahmin (ref) & & & 1.00 & \\
\hline Intercept & $0.04(0.02,0.09)$ & $<0.001$ & $0.01(0.00,0.02)$ & $<0.001$ \\
\hline
\end{tabular}

3 Models include fixed and random effects estimates for geographic clusters and control for trial arm. aOR, Adjusted

4 Odds Ratio. CI, 95\% Confidence Interval. ${ }^{1} n=822$ educated ( $\geq 1$ y schooling) vs $n=1,610$ uneducated. 